Kader

e-ISSN: 2602-2710

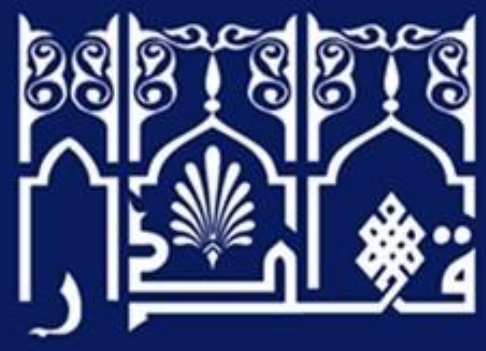

Cilt: 19, Say1: 2, 2021, ss. 522-548｜Ｖolume: 19, Issue: 2, 2021, pp. 522-548

\title{
Câhız'ın Mûcize Anlayışı: Tabiat Teorisi ve Âdet Anlayışı Çerçevesinde Bir İnceleme
}

Jāhiz's Understanding of The Miracle: An Analysis Within The Framework of Jāhiz's Theory of Nature and Understanding of Custom

\section{Meliha BILGE}

Dr., Milli Eğitim Bakanlı̆̆ı, İstanbul/Türkiye

$\mathrm{PhD}$, The Ministry of National Education, İstanbul/Türkiye

melihabilge14@hotmail.com | orcid.org/0000-0003-2638-480X | ror.org/00jga9g46

\author{
Makale Bilgisi Article Information \\ Makale Türü Article Type \\ Araştırma Makalesi Research Article \\ Geliş Tarihi Date Recieved \\ 15 Ekim $2021 \quad 15$ October 2021 \\ Kabul Tarihi Date Accepted \\ 28 Aralık 202128 December 2021 \\ Yayın Tarihi Date Published \\ 31 Aralık 2021 31 December 2021 \\ Intihal Plagiarism
}

Bu makale, iTenticate yazılımı ile taranmıştır. İntihal This article has been scanned with iTenticate

tespit edilmemiştir. software. No plagiarism detected.

Etik Beyan Ethical Statement

Bu çalışmanın hazırlanma sürecinde bilimsel ve etik

It is declared that scientific and ethical principles

ilkelere uyulduğu ve yararlanılan tüm çalışmaların have been followed while carrying out and writing

kaynakçada belirtildiği beyan olunur (Meliha Bilge). this study and that all the sources used have been properly cited (Meliha Bilge).

CC BY-NC-ND 4.0 lisansı ile lisanslanmıştır. Licensed under CC BY-NC-ND 4.0 license. 


\section{Öz}

Bu makalede ilk dönem Mu'tezilî âlimlerinden Ebû Osman el-Câhız'ın (öl. 255/869) Allah-âlem anlayışı, âdet teorisi ve mûcize görüşü ele alınacaktır. Mûcize, Mu'tezilî düşünürler tarafından peygamberlikle ilişkili olarak değerlendirilen bir konudur. Onlar, peygamberliğin ispatında tek delil olarak kabul ettikleri mûcizeyi Allah'ın kudreti altında bulunanlar ve insanların yapabildiği türden olmak üzere ikiye ayırırlar. Câhız bu iki türde gerçekleşen mûcizeyi âlemde Allah ve insanlar tarafından kurulmuş olan düzen ile açıklamış ve bu düzeni âdet kavramıyla ifade etmiştir.

Câhız, âdeti üçe ayırır. Bunların ilki, temelinde kümûn-zuhûr teorisinin bulunduğu ve âlemde genel işleyişin gereği oluşan genel kuralları ifade eden "kāim âdet"tir. Câhız'a göre kāim âdet, bilgi sahibi insanların farkında olduğu evrene ilişkin âdettir. Bu âdet Allah tarafından oluşturulmuş, akıllı ve bilgili insanlar nezdinde aşılması mümkün olmayan, bozulmaksızın devam eden, kesintiye uğramayan, karmaşanın olmadığı bir düzendir. Câhız, bu düzenin nesnelerde bulunan tabiatlar aracılı̆̆ıyla gerçekleştiğini, herkes tarafından bilindiğini fakat nadiren gidişatına engel olan ve doğal sebeplerle açıklanamayan bir durum nedeniyle tabiatların bu düzenden ayrılabileceğini belirtir. Ona göre bu durum, nesneyi belirleyici özelliği bulunan tabiatın yaratıcı tarafından yaratıldığına, düzenlenmiş bir programa göre hareket ettiğine ve gerektiğinde yaratıcı tarafından düzeninden alıkonulduğuna delildir. Bu âdet türünde Allah'ın âleme müdahalesi yani mûcize, düzenli bir şekilde devam eden "kāim âdet"in dışına çıkılmasıyla gerçekleşir. Bunların ikincisi, herkes tarafından bilinmeyen sadece belli bir bölgede yaşayan insanların bildiği "bölgesel âdet”tir. Câhız, bu âdet türünde mûcizenin bölgedeki insanlarda bilgisi bulunan âdetin Allah tarafından ihlâl edilmesiyle meydana geldiğini belirtir. Üçüncüsü ise, insanlar tarafından oluşturulmuş olan toplumsal âdettir. O, insanların yapabildiği türden mûcizeyi toplumsal âdet ile ilişkili olarak açıklamış ve bu âdet türünde mûcizenin sarfe ile yani Allah'ın insanların güdülerine veya bilgilerine müdahalesiyle gerçekleştiğini öne sürmüştür.

Bu çalışmada Câhız'ın mûcize görüşü, fizik teorisi, âdet anlayışı ve sarfeyle birlikte ele alınmıştır.

Anahtar Kelimeler: Mu‘tezile, Tabiat teorisi, Âdet anlayışı, Mûcize, Sarfe, Câhız.

\section{Abstract}

This article discusses Abū 'Uthmān al-Jāhị (d. 255/869) (one of the first Mu'tazilī scholars) Allah-world relationship, his understanding of custom, and his view on miracles. The Mu'tazili thinkers examined the problem of miracles within their concept of prophethood. They divide miracles, which they accept as the only proof of prophethood, into two: those under the power of Allah and under the power of the created. Jāhiz explains these two sorts of miracles with the order in the universe established by Allah and people and expresses this order with the concept of custom ('āda).

Jāhiz divides custom into three. The first of these is the "qāim (constant) custom", which is based on the theory of kumūn$z u h \bar{r} r$ and expresses the general rules that occur as a requirement of the general functioning in the universe. According to Jāhiz " "qāim (constant) custom" is that knowledgeable people are aware of the custom of the universe. This custom is an order created by Allah in the eyes of intelligent and knowledgeable people, which is continuous and therefore cannot be interrupted, and in which there is no chaos. He states that this order is realized through the natures in the objects, which are knowable to everyone. But rarely a nature in this order can be interrupted due to a situation that takes it out of the natural flow and cannot be explained by natural causes. According to him, this is proof that nature, which has the defining feature of the object, is created by the creator, and maintains its continuity based on an arranged program. However, the creator can involve in this order when necessary. In this type of custom, God's intervention occurs by breaking the $q \bar{a}$ im custom that continues on a regular basis. The second of these is the "regional custom", which is not known to everyone but only known to people living in a certain area. Jāhiz states that the miracle in this type of custom occurred when Allah broke the custom known to the people in the region. The third of these is "social custom" which is established by people. For Jāhiz, the miracles of this kind are under the power of people. He argues that the miracle in this type of custom occurs with sarfa, that is, by God's intervention with human's motive or knowledge.

In this study, Jāhiz's view of miracles is discussed together with his theory of nature, his understanding of custom and sarfa.

Keywords: Mu'tazila, The theory of nature, The understanding of custom, Miracle, Sarfa, Jāhiẓ. 


\section{Giriş* $^{*}$}

Mûcize, İslâm inanç esaslarından biri olan peygamberlikle yakından ilişkili olduğu için tüm Müslüman âlimler tarafından ele alınıp incelenmiş bir konudur. "A-c-z" kökünden türeyen ve bir şeyden âciz kalıp güç yetirememek, ihtiyatlı ve basîretli olmamak anlamına gelen ${ }^{1}$ mûcize, terim olarak nübüvvet iddiasında bulunan peygamberin Allah tarafından beşerin benzerini yapmaktan âciz kaldığı olağanüstü bir fiille tasdik edilmesidir. Bu nedenle kelâmcılar, olağanüstü meydana geliş özelliğiyle mûcizeye hem inanç esaslarının içinde hem de fizik teorilerinde yer verme gereği duymuşlardır. Mu'tezilî âlimler de temel prensiplerinden biri olan "Adalet" başlığı altında peygamberlikle birlikte mûcize konusuna değinmişlerdir. Onlar, peygamber olarak seçilen kişinin elinde mûcizenin meydana gelişinin zorunlu olduğunu, insanların ancak bu şekilde kimin peygamber seçildiğini anlayabileceğini savunmuşlardır. ${ }^{2}$

Mûcizenin Allah'ın fiili olduğunu ve nübüvvet iddiasında bulunan peygamberi doğrulamak amacıyla gerçekleştiğini kabul eden Mu'tezilî âlimler, diğer kelâmcılardan farklı olarak mûcizeyi ilki fiil, diğeri idrak edilme türüne göre olmak üzere iki kısımda ele alırlar: Onlar, fiil türüne göre gerçekleşenleri Allah'ın kudreti altında bulunanlar ve insanların yapabildiği türden olanlar şeklinde ikiye ayırırlar. ${ }^{3}$ Bütün Mu'tezilî kelâmcıların bu ayrımı yaptığını belirten Bâkıllânî, Eş‘arîler'den bazılarının da bu tasnifi benimsediği bilgisini verir. ${ }^{4}$ İdrak edilme şekline göre gerçekleşenler ise, hissî, aklî ve haberî mûcizelerdir. Fiil türüne göre mûcizeyi sistematik olarak tasnif edenlerden ilkinin Câhız olduğunu söyleyebilmek mümkündür. Çünkü onun öncesinde Mu'tezilî kelâmcılar tarafından peygamberin elinde gerçekleşen çeşitli mûcizelere değinilmiş, ilk döneme ait kaynaklar mevcut olmadığı için Câhız öncesinde sistematik olarak bu tasnifin yapılıp yapılmadığı tespit edilememiştir.

Fiil türüne göre yapılan bu ayırım, Mu'tezilî kelâmcıların mûcize anlayışlarına da yansımış, bu nedenle onlar mûcizeyi Allah'ın âleme ve insana müdahalesi şeklinde iki türlü ele almışlardır. Mu'tezilî âlimler, Allah'ın âleme müdahalesini Allah-âlem ilişkisi ekseninde fizik teorilerine dayalı olarak açıklamışlar, insana müdahalesini ise insan fiilleri konusuyla ilişkili olarak izah etmişlerdir. Onlar, Allah-âlem ilişkisini nesnenin niteliğini belirleyen bir tabiata sahip olduğunu kabul edenler ve tabiatı reddedenler olmak üzere iki gruba ayrılarak açıklarlar. Nesnede tabiatı kabul edenlerden İbrahim b. Seyyâr en-Nazzâm (öl. 231/845) ve Câhız, cisimlerin sınırsız sayıda bölüneceğini savunurken Mu'ammer b. Abbâd es-Sülemî (öl. 215/830) ve Ebu'l-Kāsım el-Kâ‘bî (öl. 319/931), sınırsız bölünmeyi reddederek bölünmeyen cüzün varlığını öne sürerler. Nesnenin

\footnotetext{
Bu çalışma "Mu'tezile'de Mûcize" başlıklı doktora tezi (Marmara Üniversitesi, İstanbul, 2021) esas alınarak hazırlanmıştır. / This article is prepared on the basis of doctoral dissertation titled "The Miracle in Mu'tazila" (PhD Dissertation, Marmara University, İstanbul/Türkiye, 2021).

Arif Erkan, Beyân (İstanbul: Yasin Yayınevi, 2006), 1631.

Ebü'l-Hasan Kādı'l-kudât Abdülcebbâr b. Ahmed b. Abdilcebbâr el-Hemedânî, el-Muğnî fí ebvâbi't-tevhîd XV (enNubuvvât ve'l-mu'cizât), thk. Mahmûd Muhammed Kāsım, ed. İbrahim Mezkûr-Tâhâ Hüseyin (Kāhire: ed-Dârü'lMisriyye li't-Te'lif ve't-Terceme, t.y.), 15/8, 58-59; Ebü'l-Muîn Meymûn b. Muhammed en-Nesefî, Tebsiratü'l-edille fi usûli'd-dîn, thk. Hüseyin Atay-Şaban Ali Düzgün (Ankara: Diyanet İşleri Başkanlığı Yayınları, 2. Basım, 2003), 2/28.

3 Kādî Abdülcebbâr, el-Muğnî, 15/262-263, 266; a.mlf., şerhu'l-usûli'l-hamse, thk. Abdülkerim Osman (Kahire: Mektebetü Vehbe, 2. Basım, 1408/1988), 569.

$4 \quad$ Kādî Ebû Bekr Muhammed b. Tayyib b. Bâkıllânî, Kitâbu'l-Beyân ani'l-fark beyne'l-mu'cizât ve'l-kerâmât ve'l-hiyel ve'lkehâneti ve's-sihri ve'n-narencât, thk. Richard J. McCarty (Beyrut: el-Mektebetü'ş-Şarkıyye, 1377/1958), 14.
} 
niteliğini belirleyen bir tabiatı bulunmadığını söyleyenler ise Ebü’l-Hüzeyl el-Allâf (öl. 235/849850), Ebû Alî el-Cübbâî (öl. 303/916), Ebû Hâşim el-Cübbâî (öl. 321/933) ve Kādî Abdülcebbâr'dır (öl. 415/1025).

Mu'tezilî âlimler, insanların gücü altında bulunan ve yapabildiği türden mûcizeleri açıklama konusunda da iki gruba ayrılmışlardır: Nazzâm, Câhız ve Kâ‘bî̀den oluşan birinci grup, bu tür mûcizelerin Allah'ın insanı güdülerinden engellemesi ve alıkoyması yani sarfe ile gerçekleştiğini öne sürerler. ${ }^{5}$ Ebû Alî el-Cübbâî, Ebû Hâşim el-Cübbâî ve Kādî Abdülcebbâr'dan oluşan ikinci grup ise insanın veya peygamberin fiillerine Allah'ın doğrudan müdahalede bulunmasıyla mûcizenin meydana geldiğini kabul ederler. ${ }^{6}$

Mu'tezilî kelâmcılar, mûcize öncesinde âlemde Allah tarafından kurulmuş bir düzenin varlığını ortaya koymaya büyük özen göstermişlerdir. Çünkü mûcize, bu kurulu düzeni ihlâl ederek gerçekleşen olağanüstü bir hadisedir. Onlar, âlemde kurulu olan bu düzeni açıklamada ikiye ayrılır: Nazzâm, Câhız ve Kâ‘bî, bu düzenin nesnelere konulan tabiat aracılığıyla gerçekleștiğini savunur ve Allah'ın âleme müdahalesini yani mûcizeyi "düzenli âdetin dışına çıkan" şeklinde ifade ederler. ${ }^{7}$ Ebü'l-Hüzeyl, Ebû Alî el-Cübbâî, Ebû Hâşim el-Cübbâî ve Kādî Abdülcebbâr ise âlemdeki düzenin ve her türlü değişimin Allah'in iradesi ve kudretine göre meydana geldiğini öne sürerek mûcize için âdeti bozan anlamında "nakżu'l-âde" ${ }^{8}$ kavramını kullanırlar. ${ }^{9}$ Her iki grupta yer alan Mu'tezilîâlimler, mûcizenin Allah'ın âleme doğrudan müdahalesi ile gerçekleştiğini kabul ederler. Mu'tezilî düşünürler, âlemin oluşum ve değişimine ilişkin farklı fizik teorilerini ortaya koysalar da âlemdeki düzeni "âdet" kavramıyla ifade etmişlerdir. Fakat onların her birinin savunduğu âdet anlayışının temelinde kendi fizik teorileri yer almaktadır. Câhız'nn kümûn-zuhûra ve tabiata dayalı âdet anlayışı, Kâ‘bînnin cevher-i ferd ve tabiat temelli âdet anlayışı, Kādî Abdülcebbâr'ın cevher-i ferd ve anti-tabiatçllığa dayalı âdet anlayışı gibi. Mu'tezilî düşüncedeki her bir âdet anlayışı, zemininde bulunan fizik teorisine göre şekillenmiştir. Örneğin Câhız, mûcizenin âdetin dışına çıkarak meydana geldiğini şu şekilde ifade eder: “و باشياء كثيرة خرجت خارجية من نسق العادة (Allşılmış düzen veya genel işleyişten kesin bir şekilde çıkan birçok nesne vardır.)" ${ }^{" 10}$ Kâdî Abdülcebbâr ise

Ebû Osman Amr b. Bahr el-Câhız, Kitâbü'l-Hayevân, thk. Abdüsselâm Muhammed Hârûn (Kāhire: Mektebetu Mustafa el-Babi el-Halebî ve Evlâduhu, 2. Basım, 1385/1965), 4/89-92; 6/268-270; Abdullah b. Ahmed b. Mahmûd Ebu'l-Kāsım el-Belhî el-Kâ‘bî, Kitâbü'l-Makālât ve meahu uyûnu'l-mesâil ve'l-cevâbât, thk. Hüseyin Hansu-Râcih Kürdî-Abdülhamid Kürdî (İstanbul: Kuramer- Amman: Dârüll-Feth, 2018), 284-285; Ebü'l-Hasan Ali b. İsmail el-Eş‘arî, Makālâtü’lİslâmiyyîn ve'htilâfui'l-musallîn, nşr. Helmut Ritter (Weisbaden: Franz Steiner Verlag, 1400/1980), 225; Alî b. Hüseyin Şerîf el-Murtazâ, ez-Zahîre fí ilmi'l-kelâm, nşr. Ahmed el-Hüseynî (Kum: Müessesetü'n-Neşri'l-İslâmî, 1411/1990), 379; Ebü'l-Hasan Alî b. Muhammed b. Habib el-Mâverdî, en-Nüket ve'l-uyûn tefsîru'l-Maverdî, thk. es-Seyyid b. Abdülmaksud b. Abdürrahim (Beyrut: Dârü'l-Kütübi'l-illmiyye, 1412/1992), 1/33; Fahreddin er-Râzî, Muhammed b. Ömer b. Hüseyin, Nihâyetül'-îcâz fi dirâseti'l-ícâz, thk. Nasrullah Hacımüftüoğlu (Beyrut: Dâru Sâdır, 424/2004), 26; Cemâleddîn Ebû Mansur Hasan b. Yusuf el-Mutahhar Allâme el-Hillî, Menâhicu'l-yakîn fí usûli'd-dîn, thk. Muhammed Rıza el-Ensârî el-Kummî (Kum: Yârân, 1416/1995), 276.

$6 \quad$ Kādî Abdülcebbâr, el-Muğnî, 15/196, 266; a.mlf., el-Muğnî fí ebvâbi't-tevhîd XVI (İcâzül'-Kur'an), thk. Emîn el-Hûlî, ed. İbrahim Mezkûr-Tâhâ Hüseyin (Kahire: ed-Dârü'l-Misriyye li't-Te'lif ve't-Terceme, t.y.), 16/219, 322-323.

Josef van Ess, Nazzâm ve Kâ‘bî’nin âdet kavramını kullandıkları bilgisini verir. bk. Josef van Ess, "Mu'tazilah”, The Encyclopedia of Religion, ed. Mircea Eliade (New York: Macmillan Publishing Company, 10/227.

$8 \quad$ Kādî Abdülcebbâr, el-Muğnî, 15/182, 183.

$9 \quad$ Kādî Abdülcebbâr, el-Muğnî, 15/184, 188; 16/231.

10 Câhı, Kitâbü'l-Hayevân, 4/82. 
mûcizenin, nakżu'l-âde ${ }^{11}$ yani insanlar tarafından bilinen âdetin Allah tarafından nakzedilerek gerçekleştiğini şu sözleriyle ortaya koyar:

(Çünkü âdetin nakzedilmesinde ve ona itibar edilmesinde temel amaç, meydana gelen olağanüstü durumun yani mûcizenin (fiilî) tasdik şeklinde Allah tarafindan yapıldığını bilinmesidir."'12

Âdet kavramının sebepliliği reddetmek amacıyla ortaya çıktığı ve Eş‘arîler ile Basra Mu'tezilesi tarafından kullanıldığı öne sürülmüştür. ${ }^{13}$ Fakat Josef van Ess, temelinde sebepliliği barındıran tarzda âdet kavramının kullanımını Nazzâm'a nispet ederek "Allah'ın âdeti” şeklinde kullandığı bilgisini verir. ${ }^{14}$ Aynı kavram ve kullanım, nesnede tabiatı kabul eden Kâ‘bî'de de mevcuttur. ${ }^{15}$ Onlar, âdet ile Allah tarafından oluşturulan "genel işleyişe bağlı genel kuralları" yani sebep-sonuç ilişkisi şeklinde ortaya çıkan ilâhî kanunları kastetmişlerdir. Josef van Ess'in gündeme getirdiği bu âdet kavramının ve anlayışının izlerini, Nazzâm'ın öğrencisi Câhız'ın eserlerinde açık bir şekilde bulmak mümkündür. Câhız, mûcize öncesinde kurulu bir düzenin varlığını açıklamada bu kavramı kullanmış, âdet anlayışını genel Mu'tezilî düşüncede yer alan mûcize türlerine göre şekillendirmiştir. O, Allah'ın kudreti altında gerçekleşen mûcizelerin, "kāim veya yerleşik âdet" ve "bölgesel âdet"in bozulmasıyla gerçekleştiğini söylerken insanların yapabildiği türden mûcizelerin sarfe ile meydana geldiğini öne sürmüş ve bu konuyu "toplumsal âdet" ile ilişkili olarak ele almıştır.

Asıl adı Ebû Osman Amr b. Bahr olan Câhız, Nazzâm ekolünde yetişen ve hocasından sonra Basra Mûtezilesi'nin reisi kabul edilen Mûtezilî kelâmcılardan birisidir. 0 , kelâm ilminin önemine değinerek bu ilimle uğraşan kimselerin tabiat ilimlerini ve felsefeyi bilmelerinin gerekli olduğunu vurgular. Onun kelâmî görüşlerinin şekillenmesinde hocası Nazzâm'ın çok büyük etkisi olmuştur. ${ }^{16}$ Yaşadığı dönemde Câhız, çeşitli felsefî ve dinî akımları savunan kimselerle münazaralar yaparak ilmî tartışmalarda yerini almıştır. ${ }^{17}$

Mûcizeyi "âyât, burhân, acâib, alâmât, a'lâm ve delâil” kelimeleriyle ifade eden Câhız ${ }^{18}$, Allah'ın peygamberlerini tasdik etmek amacıyla yarattığı, insanların güçleri dışına çıkan ve hiçbir şekilde

$11 \quad$ Kādî Abdülcebbbâr, el-Muğnî, 15/183, 186, 188.

12 Kādî Abdülcebbâr, el-Muğnî, 15/183.

13 Temelinde zorunsuzluğun yer aldığı âdet anlayışı İbn Hazm tarafından Eş‘arîler'e nispet edilir. Ona göre Eş‘arîler, mûcizelerin ihlâl ettiği olayların normal akışını ifade etmede tabiat yerine "âdet" terimini kullanmışlardır. bk. H. Austryn Wolfson, Kelâm Felsefeleri Müslüman-Hıristiyan-Yahûdî Kelamı, çev. Kasım Turhan (İstanbul: Kitabevi Yayınları, 2001), 416-418; Muhammed Âbid el-Câbirî, Arap İslâm Kültürünün Akıl Yapısı, çev. Burhan Köroğlu-Hasan Hacak-Ekrem Demirli (İstanbul: Kitabevi Yayınları, 2. Basım, 2000), 271-272.

14 “Tıpkı Nazzâm gibi Kâ‘bî de Allah'ı âdeti kavramına dayanarak cisimlerin fiillerine karar veren ve türün devamını sağlayan tabiî niteliklerin var olduğuna inandı." bk. Ess, "Mu'tazilah", 10/228.

15 Ess, Kâ‘bî’nin düşüncesini şu şekilde aktarır: "Kâ‘'bî bu konuda Allah'ın âdetinden bahsetti. Allah, âdetini (the coutume de Dieu) sadece mûcize olgusu için bozar." bk. Ess, "Mu’tazilah”, 10/227.

16 Yunus Cengiz, Doğa ve Öznellik Câhı’’in Ahlak Düşüncesi (ìstanbul: Klasik Yayınları, 2015), 1-40.

17 Câhı, Kitâbü'l-Hayevân, 1/11; 2/110; 6/206.

18 Câhız, ayrıca mûcizeyi hayrete düşüren, şaşırtan, görülmemiş ve duyulmamış anlamında "acâib" ve en hayret verici olaylar anlamında "a'cebu'l-umûr" kavramlarıyla ifade eder. bk. Câhız, "Hucecü’n-nubuvve", Resâilü'l-Câhız, thk. Abdüsselâm Muhammed Hârûn (Beyrut: Dârü'l-Ceyl, 1411/1991), 3/226, 240, 250, 252, 259, 264, 270, 280; a. mlf., Kitâbül'-Hayevân, 4/80. 
benzerini yapamadıkları olayları mûcize olarak niteler. Peygamberin doğruluğuna delil olarak meydana gelen bu olguların "insanlar tarafından yapılamamasını ve ondan âciz oluşlarını" tanımında en önemli şart olarak ortaya koyan Câhız, mûcizenin sadece Allah'ın fiili ve yaratılmışların (insanlar ve cinler) yapamadığı türden olduğunu belirtir. Ona göre bir olayın mûcize olabilmesi için Allah'ın fiili olması, insanların gücünü aşarak vuku bulması, peygamberlik iddiasında bulunan kişinin elinde ve iddiasına uygun olarak gerçekleşmesi gerekir. Bu şartları taşımayan olguların mûcize olarak nitelenmesi doğru değildir. ${ }^{19}$

Câhız'nn Allah-âlem ilişkisi ve sarfe düşüncesini konu edinen modern dönem literatürde bazı çalışmalar bulunmaktadır. ${ }^{20}$ Fakat Câhız'ın mûcize anlayışına hasredilmiş müstakil bir çalışma mevcut değildir. Bu çalışmada Câhız'nn mûcize anlayışı, Mu'tezilî âlimlere has olan mûcize türleriyle ilişkili bir şekilde ele alınacaktır. Bu yönüyle onun mûcizeye yaklaşımının diğer kelâmcılardan farklı olduğunu belirtmek gerekir. O, mûcizeleri Allah'ın kudreti altında bulunanlar ve insanların yapabildiği türden olanlar şeklinde iki türlü değerlendirmeye tabi tutmuş, ilkini fizik teorisi ve kümûn-zuhûra dayalı âdet anlayışıyla diğerini ise sarfe görüşüyle açıklamıştır. Bu makalede Câhız'ın "kāim, bölgesel ve toplumsal" olmak üzere üç tür âdet anlayışına sahip olduğunu ve mûcizeyi ilâhî müdahaleyle bu âdetlerin dışına çıkılması şeklinde izah ettiğini öne sürüyoruz. Bu şekilde Câhız’nn mûcize anlayışını açıklığa kavuşturma çabası içinde olacağız.

\section{Câhı'ın Fizik Teorisi}

Câhız, nesnelerin özelliklerini belirleyen bir tabiata sahip olduğunu savunan Mưtezilî kelâmcılardan biridir. Onun öne sürdüğü veriler ve yaklaşımlar fizik teorisinde hocası Nazzâm'a tabi olduğu izlenimini vermektedir. Nazzâm'in savunduğu kümûn-zuhûr teorisine göre evrendeki her şey bir anda, birlikte ve iç içe geçmiş bir hâlde yaratılmıştır. Bu yaratılmayı Nazzâm, "evrendeki tüm cisim veya nesnelerin tek bir mekânda iç içe geçmiş bir hâlde birbirinin içinde gizlenerek bulunması" anlamına gelen kümûn kavramıla ifade eder. Ona göre varlıkların tümü daha önce yaratıldığı için var olma, ancak gizlenmiş olanın ortaya çıkmasıyla gerçekleşir. Bu nedenle zuhûr "cismin içinde gizli olarak bulunan bu nesnelerin gizlendikleri yerden tabiatlarına uygun bir şekilde cismin dışına çıkışına” verilen isimdir. ${ }^{21}$ Câhız, hocası Nazzâm'ın savunduğu bu

19 Câhız, "Hucecü'n-nubuvve", 3/259-261.

20 Câhız’ın tabiat düşüncesini ele alan modern eserler şunlardır: Ali Ebû Mülhim, el-Münahi'l-felsefî inde’l-Câhız (Beyrut: Dâru't-Tali'a li't-Tıba‘ ve'n-Neşr, 1988); Osman Demir, Kelâmda Nedensellik İlk Dönem Kelâmcılarında Tabiat ve İnsan (İstanbul: Klasik Yayınları, 2015); Yunus Cengiz, Doğa ve Öznellik Câhız’n Ahlâk Düşüncesi (İstanbul: Klasik Yayınları, 2015); Yunus Cengiz, “Câhız; Doğa Temelinde İnsan üzerine Düşünmek”, Doğudan Batıya Düşüncenin Serüveni: İslâm Düşüncesinin Altın Çağı V, ed. Abdullah Kahraman (İstanbul: İnsan Yayınları, 2015), 5/543-572; Mehmet Baktır, “Câhız'ın Varlık ve Tabiat Anlayışı” (C.Ü. İlahiyat Fakültesi Dergisi 10/2, 2006), 237-256; Yasemin Holoğlu, Câhız'da Tabiat Felsefesi (İstanbul: Marmara Üniversitesi, Sosyal Bilimler Enstitüsü, Yüksek Lisans Tezi, 2014). Câhız'1n tabiat düşüncesiyle birlikte mûcize anlayışa kısmen değinen çalışmalar ise şunlardır: Ahmet Mekin Kandemir, Mu'tezilî Düşüncede Tabiat ve Nedensellik (İstanbul: Endülüs Yayınları, 2019); Mehmet Baktır, "Câhız'1n Nübüvvet Anlayışı", (C.Ü. İlahiyat Fakültesi Dergisi 10/2, 2006), 257-268.

21 “Allah insan, bitki, cansızları bir anda yaratmış, Âdem'in ve annelerin yaratılması çocukların yaratılmasından önce olmamıştır. Allah, eşyanın büyük bir kısmını bazısının içine gizlemiştir. Zaman bakımından öncelik ve sonralık eşyanın yaratılışında değil, gizlendikleri yerden ortaya çıkışındadır." bk. Ebü’l-Hüseyin Abdürrahim b. Muhammed b. Osman el-Hayyât, Kitâbü'lIntisâr ve'r-red âlâ İbn Râvendî el-mülhid, thk. H. S. Nyberg (Beyrut: Mektebetü'd-Dâri'l-Arabiyyeti li'l-Kitab, 1993), 5152. Buna benzer bir ifade Şehristânî'de de mevcuttur. bk. Ebü'l-Feth Muhammed b. Abdilkerim eş-Şehristâni, Kitâbü'l-Milel ve'n-nihal, thk. Muhammed b. Fethullah Bedrân, (Kahire: Mektebetü'l-Enclo'l-Mısriyye, 2. Basım, 
teoriyi kabul ettiğini net bir şekilde dile getirmemiştir. Fakat cisimlerin sınırsız sayıda alt bileșenlerinin (cisimler) bulunduğunu, bunların her birinin belirleyici bir tabiata sahip olduğunu, onların sadece zuhûr etmeleri durumunda ve tecrübe edilerek bilinebileceğini söylemesi ${ }^{22}$, odunun içinde gizlenmiş olan ateşin ${ }^{23}$ zıddı olan soğukluğa baskın gelemediği için gizlendiği yerden çıkamadığını iddia etmesi ${ }^{24}$ onun kümûn-zuhûr teorisini benimsediği izlenimini vermektedir. Câhız, ayrıca nesnedeki alt bileşenlerin devamlı bir şekilde birbirine etkide bulunduğunu ve kuvvetli olanın güçsüz olanı baskıladığını kabul etmiş ${ }^{25}$, nesnede gizlenmiş olan alt bileşenin cismin dışından gelen bir etkenle birleşerek kendisini baskı altında tutan engeli aşmasını ise, yoktan var olma şeklinde değil, cisimde gizlenmiş olanın dış ortama çıkışı (zuhûr) olarak görmüştür. ${ }^{26} \mathrm{Bu}$ veriler doğrultusunda onun hocasının fizik görüşüne yakın durduğunu söyleyebilmek mümkündür.

Câhız’ın fizik teorisine göre sınırsız sayıda bölünen cisimlerin içinde sınırsız sayıda alt bileşen mevcuttur. ${ }^{27}$ Alt bileşenler, tedâhül yoluyla iç içe geçmiş bir hâlde ve gizlenmiş olarak cismin içinde bulunur. ${ }^{28}$ Alt bileşenlerin cismin içindeki yerleşimi, "ölçüsü az kuvveti çok olanın, ölçüsü çok kuvveti ă̆ır olanı işgal etmesi" biçimindedir. ${ }^{29}$ Cisimde bulunan tüm alt bileşenler cismin tabiatını oluşturarak cismin bilinmesini sağlar. ${ }^{30}$ Varlıkların bilinmesinin tabiatlarının bilinmesine bağlı olduğunu ${ }^{31}$ ifade eden Câhız, varlıkların genel ve ayırıcı tabiatlarının bulunduğunu söyler. 0 , varlıklarda bulunan genel tabiatı yani temel nitelikleri "tab" veya "tabîa" kavramıyla ifade ederken genel tabiatın meydana gelişinden sonra ortaya çıkan ikincil özellik ya da ayırıcı tabiat için "garîze"yi kullanır. ${ }^{32}$ Cisimlerin tabiatına suyun akıcı, karın soğuk ve ateşin sıcak olmasını örnek veren Câhız, karın soğukluğunun rahatlatıcı özelliğe sahip oluşunun ayırıcı tabiatı olduğunu belirtir ve durumu ayırıcı tabiat için kullandığı garîze kavramılla ifade eder. ${ }^{33}$

Onun fizik teorisinde cisimlere ve alt bileşenlere tabiatını veren ve mahallinde cismi tabiatlarıyla birlikte yaratan Allah'tır. ${ }^{34}$ Cisimlerden meydana gelen her bir fiil yaratılış gereği (bi îcâbi'l-

1328/1910), 1/57; Meliha Bilge, Ebû İshak İbrahîm b. Seyyâr en-Nazzâm'ın Mûcize Anlayışı: Nazzâm'ın Tabiat Teorisi Çerçevesinde Bir İnceleme", KADER (18/2, 2020), 587-616.

22 Câhız, Kitâbül-Hayevân, 5/11-40; Cengiz, Doğa ve Öznellik, 47.

${ }^{23}$ Câhı, Kitâbül-Hayevân, 5/11-40.

24 Câhı, Kitâbü'l-Hayevân, 5/21.

25 Câhı, Kitâbü'l-Hayevân, 5/20-21, 81-82; Cengiz, Doğa ve Öznellik, 42-44.

26 Câhız, Kitâbü'l-Hayevân, 5/81-82; Cengiz, Doğa ve Öznellik, 47.

27 Câhız, Kitâbü'l-Hayevân, 5/11; Demir, Kelâmda Nedensellik, 166.

28 Câhız, Kitâbü'l-Hayevân, 5/11, 20-21, 81-82. Tedâhül, iki cisimden birinin diğerinin içine girerek gizlenmesine denir. Nazzâm'in düşüncesine göre nesneler, birbirlerinin içinde tedâhül yoluyla yani iç içe geçmiş bir halde bulunurlar. Bu şekilde cismin mahalli tek bir yer olur. bk. Kâ‘bî, Kitâbü'l-Makālât, 481. Eş‘arî, “íki cisimden birinin mekânının ya da mahallinin diğer cismin de mekânı olmasını tedâhül” olarak tanımlar. bk. Eş‘arî, Makālât, 327.

29 Eşarîi, Makālât, 327.

30 Câhız, Kitâbü'l-Hayevân, 5/11-12.

31 Câhız, Kitâbül'-Hayevân, 1/148; Cengiz, Yunus, “Câhız; Doğa Temelinde İnsan üzerine Düşünmek”, 5/546.

32 Câhı, Kitâbül'-Hayevân, 2/146, 3/373, 5/44; Cengiz, Doğa ve Öznellik, 46.

33 "Eğer soğukluğun canlılar için rahatlatıcı özelliği olmasaydı, canlılar rahatlayamazdı. (Canllar rahat nefes alıp veremezdi.)" $\mathrm{Bu}$ durumda garîze, cismin temel tabiatının zuhûrundan sonra cisimde varlı̆̆1 keşfedilen ve bilinen ikinci nitelik gibidir. bk. Câhız, Kitâbü'l-Hayevân, 5/44; Cengiz, Doğa ve Öznellik, 46.

34 "Allah, yaratılış gereği tabiatın fiilini içinde bulunduracak şekilde cismi yaratır. Cismin tabiatının fiilinin çıkmasııı gerektiren bir sebebin ihdâs edilmesi ile birlikte fiil, cisimden zorunlu olarak meydana gelir." bk. Kâ‘bî, Kitâbü'l-Makālât, 475-476. 
hılkati) cisimde mevcuttur. ${ }^{35}$ Kādî Abdülcebbâr da bu konuyla ilgili onun cismi tabiatıyla yaratanın ve onu mahallinde bulunduranın Allah olduğu görüşünü benimsediğini belirtir. ${ }^{36}$ Bu nedenle mahallinde bulunan cismin tabiatına uygun olarak ortaya çıkan tüm fiilleri, yaratılış gereği Allah'a aittir. ${ }^{37} \mathrm{O}$, evrendeki işleyişin bu tabiatlar vasitasıyla gerçekleştiğine ve meydana gelenlerin her birinin Allah'ın dolaylı (vasıtalı) fiili olduğuna işaret eder.

Bu teoride yaratıldığı andan itibaren cisimde var olan bir hareket mevcuttur. Bu hareket, cismin içindeki alt bileşenlerin itme-çekme şeklinde birbirine uyguladığı "i'timâd hareketi" dir. ${ }^{38}$ Birbirine kuvvet uygulayan alt bileşenlerin bir arada bulunmasıyla cismin iç dinamiği oluşur ${ }^{39}$ ve alt bileşenlerdeki bu hareketlilik cismin dengede kalmasını sağlar. ${ }^{40}$ Cismin içindeki tüm alt bileșenler, gücü oranında bu hareketliliğe katılır ve bu hareketliliğin sonunda her bir cisim kendi kaynağına dönme çabası içinde olur. ${ }^{41} \mathrm{Bu}$ nedenle odunda bulunan küller, toprak ve suya yönelirken ateş yukarıya doğru ${ }^{42}$, ağır ise aşağıya doğru yönelim içinde olur. ${ }^{43}$ Serbest kaldığında ateş yukarıya doğru gider, su aşağıya doğru hareket eder ve taş aşağı düşere. ${ }^{44}$

Câhız'a göre cismin dengesinin devamlılı̆̆ı, alt bileşenlerinin birbirine uyguladığı çekme-itme hareketiyle sağlandığı için bu hareketlilik devam ettiği sürece cisim aynı kalır. Cismin değişimi, cisimdeki denge hâlinin bozulmasıly gerçekleşir. Cismin denge hâlinin bozulması ise, "Allah'ın doğrudan müdahalesi ve arazları yaratmasıyla değil”, "bileşik ve zıt halde bulunan cismin içindeki tabiatların dengesinin bozulmasıyla yani cismin içinde gizlenmiş hâlde bulunan alt bileşenlerden birinin veya birkaçının cismin dışına çıkışıyla (zuhûr)" meydana gelir. Cismi oluşturan bileşenlerin farklı tabiatlara sahip olduğunu ifade eden Câhız, odunun içinde alt bileşen olarak ateşin gizli olduğunu ve diğer bileşenlerle etkileşim içinde bulunduğunu söyler. ${ }^{45}$ Odunda gizli hâlde bulunan ateş, zıddı olan soğukluğa baskın gelemediği için gizlenmiş olduğu yerden

35 Kâ‘bî, Kitâbü'l-Makālât, 476; Eş‘arî, Makālât, 404.

36 Ebü'l-Hasan Kādı'l-kudât Abdülcebbâr b. Ahmed b. Abdilcebbâr el-Hemedânî, el-Muhît bi't-teklîf li'l-Kādî Abdilcebbâr cemea el-Hasan b. Ahmed b. Metteveyh, thk. Ömer Seyyid Azmî (Kāhire: ed-Dârü'l-Mısriyye li't-Te'lîf ve't-Terceme, t.y.), 386.

37 Hayyât, el-İntisâr, 46-47; Cengiz, “Nazzâm'ın Düşüncesinde Tanrı, Doğa ve İnsan”, Doğudan Batıya Düşüncenin Serüveni: İslâm Düşüncesinin Altın Çağı V, ed.Abdullah Kahraman (İstanbul: İnsan Yayınları, 2015), 5/591-592. “Allah, taşa taş olma tabiatını vermiş ve bu tabiatla onu yaratmıştır. Taşın atıldığı zaman gitme sebebi budur, fakat atılma kuvveti son noktaya ulaştığında taş tabiatı gereği yere düşer." bk. Kâ‘bî, Kitâbü’l-Makālât, 360. Aynı bilgiyi Şehristânî de verir. bk. Şehristânî, el-Milel ve'n-nihal, $1 / 57$.

38 Cengiz, “Nazzâm'ın Düşüncesinde Tanrı, Doğa ve İnsan”, 5/585.

39 Câhız, Kitâbü'l-Hayevân, 5/11-12; Cengiz, Doğa ve Öznellik, 42; a. mlf., "Nazzâm'ın Düşüncesinde Tanr1, Doğa ve İnsan”, 5/586, 588 .

40 Josef Van Ess, “Abû Eshâq al-Nazzâm”, Encyclopedia Iranica, ed. Ehsan Yarshater (London: Routledge and Kegan Paul, 1985), 1 / 277-278.

41 Câhı, Kitâbü'l-Hayevân, 5/15-16.

42 Câhız, Kitâbü'l-Hayevân, 5/81-82; Cengiz, "Nazzâm'ın Düşüncesinde Tanrı, Doğa ve İnsan”, 5/589.

43 "Ağır olan serbest bırakıldığında Allah tarafından yaratılan tabiatı gereği aşağıya inerken hafif olan Allah tarafından yaratılan tabiatı gereği yukarıya doğru yükselir. bk. Hayyât, el-intisâr, 40.

44 Câhız, Kitâbü'l-Hayevân, 5/38-39; Hayyât, el-İntisâr, 40; Cengiz, "Nazzâm'ın Düşüncesinde Tanrı, Doğa ve İnsan”, $5 / 584$.

45 Câhız, Kitâbü'l-Hayevân, 5/11-40. 
çıkamaz. ${ }^{46}$ Çünkü soğukluğa tek başına baskın gelebilecek güce sahip değildir. Fakat cisme dışarıdan bir ateş yaklaştırıldığında içeride gizlenmiş olan ateş, bu ateşle birleşerek kendisini baskı altında tutan soğukluğa üstün gelerek gizli hâlde bulunduğu yerden nesnenin dışına çıkar. ${ }^{47}$ $\mathrm{Bu}$ şekilde içeride gizlenmiş ateşin dışarı çıkışıyla yanma meydana gelir. ${ }^{48}$ Bu konuda Câhız, yanmanın sürtünme ile olmadığını, dışarıdan cisme etki edenin içeride gizli olan alt bileșeni etkilemesiyle gerçekleştiğini öne sürmüştür. ${ }^{49}$ Câhız, ateş örneğinden hareketle nesnenin içinde gizlenmiş ve hareket hâlinde cisimlerin bulunduğunu, bu cisimlerin her birinin ayrı tabiatlara sahip olduğunu ve kendi tabiatlarına uygun olanı gerçekleştirme ${ }^{50}$ gayesinde olduğunu belirtir. Nesnede bulunan ve devamlı bir şekilde birbirini etkileyen alt bileşenlerden bazıları ortamın da katkısıyla güçlenerek farklı harekete sahip olmakta ${ }^{51}$ cismin içindeki hareket sürekli olduğu için alt bileşenlerden kuvvetli olanlar, zayıf olanları bastırmaktadır. Câhız, cismin içinde gizlenmiş hâlde bulunan alt bileșenlerden birinin dış bir etkenle birleșip baskıdan kurtulmasını yoktan var olma değil, gizlenenin açığa çıkması yani zuhûr olarak kabul etmiştir. ${ }^{52}$

\subsection{Allah'in Âleme Müdahalesi}

Câhız, Allah'ın âlem ve insanlara müdahalede bulunmasının mümkün olduğunu söylemiştir. Onun âleme ilâhî müdahaleyi nesnelerle ilişkili olarak ele aldığını ve bu durumu kümûn-zuhûra göre izah ettiğini söyleyebilmek mümkündür. Yukarıda da ifade edildiği üzere kümün-zuhûra göre cisme dışarıdan bir etkide bulunulması durumunda cismin dengesi bozulur. Dengenin bozulmasıyla kastedilen cisimde gizli bir şekilde bulunan alt bileşenin cismin dışına çıkışıdır. Bu durum her bir cisim için dağılıp bozulabilme sürecinin mümkün olduğunu gösterir. Bu teoride tabiatına uygun bir şekilde bozulma sürecine girmiş tüm cisimler dış bir engel nedeniyle durdurulabilir..$^{53} \mathrm{Bu}$ duruma yanmayla dengesi bozulan odunun üzerine su atılması ve yanmanın

46 Bu duruma pamuk, odun ve elbise örnek verilebilir. Alt bileşenlerinin dengede hâlinde bulunmasıyla nesnelerde değişim olmayacağı ve aynı kalacağı ifade edilen bu görüşe göre ateşin yaklaşmasıyla denge bozulur. Pamuk veya elbiseye dışarıdan bir ateş yaklaştırıldığında içeride gizlenmiş olan sıcaklık alt bileşeni, dışarıdan gelen ateşle birleşerek baskıdan kurtulup yerini terk eder ve yanma gerçekleşir. Bu durumda elbise veya pamuğun yanmasının sebebi, dışarıdan gelen ateş değil, kendilerinde gizlenmiş olarak bulunan baskı altında kalmış sıcaklıktır. Normal şartlar altında elbise veya pamukta gizlenmiş olan bu sıcaklık, diğer alt bileşen soğukluk tarafından baskı altında tutulduğu için elbise veya pamuktan dışarı çıkması mümkün değildir. Soğukluk tarafından engellenen veya baskılanan bu sıcaklık, dışarıdan gelen ateşle birleştiğinde ondan destek alarak kendisine kuvvet uygulayan ve çıkmasına engel olan soğukluğu bastırır ve nesnenin dışına çıkar. bk. Câhız, Kitâbü’l-Hayevân, 5/20-21; Demir, Kelâmda Nedensellik, 166.

47 Câhız, Kitâbü'l-Hayevân, 5/7.

48 Câhız, Kitâbü'l-Hayevân, 5/20-21.

49 Câhız, Kitâbü'l-Hayevân, 5/11-40.

50 Câhı, Kitâbül'-Hayevân, 5/11-40. Bu fizik teorisinde bir cismin sahip olabileceği tüm niteliklerin her nesnede bulunduğu savunulur. Buna göre odunda ağırlık, hafiflik, sıcaklık, soğukluk ve diğer tüm nitelikler mevcuttur. Odundaki her bileşen, hedefine varma peşinde olduğu için aralarında sürekli bir mücadele vardır. Bu mücadelenin sonunda gücü azalanlar pasif kalmakta, gücünü artıranlar ise pasif kalanları bastırmaktadır. bk. Câhız, KitâbülHayevân, 5/20-21; Eş'arî, Makālât, 327; Josef van Ess, “Abû Eshâq al-Nazzâm”, 1/277-278.

51 Câhız, Kitâbü'l-Hayevân, 5/20-21, 81-82; Cengiz, Doğa ve Öznellik, 42-44.

52 Câhız, Kitâbül'-Hayevân, 5/81-82; Cengiz, Doğa ve Öznellik, 47.

53 Hayyât, el-İntisâr, 45. "Odun tamamen yanmadan önce ateşin söndürüldüğünde dağılıp bozulma sürecine engel olunmuş ve bu şekilde içinde az miktarda ateş taşyyan kömür üretilmiştir." bk. Josef van Ess, "Ebû İshak en-Nazzâm Örneği Üzerinden Kelâm-Bilim İlişkisi”, çev. Mehmet Bulğen, Marmara Üniversitesi İlahiyat Fakültesi Dergisi 46 (Nisan 2014), 282-283. 
durdurulması örnek verilebilir. Böylece tamamen yanmadan söndürülen odunun bozulma süreci engellenerek içinde ateş bulunduran odun kömürüne dönüşmesi sağlanır. ${ }^{54}$ Yanma olayından hareketle cisimlerle tabiatlarını bir arada tutan ve yaratanın Allah olduğunun ifade edildiği bu anlayışta varlıkları tabiatları dışında bir duruma Allah'ın yönlendirebileceği de kabul edilir..$^{55} \mathrm{Bu}$ görüş, Hayyât tarafından şu şekilde aktarılmıştır: "Allah zıt nesneleri bulundukları durumdan kurtulmalarını sağlayarak birleşmeye zorlar. Zıt olanın zıtlığına engel olunması ve birleşmeye zorlanmasına gelince cevherinde veya tabiatında birleşme olan cisimler, zorlandiğında (güç kullanıldığında); cevherinde ve tabiatında itme olan (birleşme engeli olan) cisimler ise, bu durumdan hali olup engelleri ortadan kalktı̆ıında birleşebilirler. Suyun özelliği veya tabiatı akıcı olmak, ağır taşın özelliği yuvarlanmak ve ateşin özelliği alev saçmak ve yükselmektir. Tüm bu sayllanların özellikleri (denilen şekilde) engellendiğinde tabiatlarında olanın gerçekleşmesi mümkün değildir. ${ }^{" 56}$ Buna göre Allah, karşıt nesneleri tabiatlarında mevcut olmayan birleşmeye zorlayabilir. Bunu da birleşmelerine engel olan durumu aralarından kaldırmakla yapar. Tabiatlarında birleşme olan cisimleri ise zorlama ve kuvvet uygulayarak birbirinden ayırır. Bu şekilde cisme müdahalenin mümkün olduğu ve tabiatı gereği yaygın bir şekilde ortaya çıkandan farklı bir durumun Allah'ın doğrudan müdahalesiyle gerçekleşebileceği öne sürülür. ${ }^{57}$ Fakat bu teoride gözden kaçırılmaması gereken en önemli husus, nesnelerdeki tabiatın yaratıcısının Allah olması sebebiyle tabiatla gerçekleşenlerin Allah'a ait dolaylı fiiller olarak kabul edilmesidir. Mûcize ise Allah'ın dolaylı fiili değil, peygamberin nübüvvet iddiası esnasında doğrudan müdahaleyle ortaya çıan fiilidir, yani mûcize Allah'ın nesneye anlık doğrudan müdahalesiyle yaygın genel tabiatın dışındaki bir tabiatın işlevsel hâle gelmesidir. ${ }^{58} \mathrm{Bu}$ teoride nesnede sınırsız sayıda tabiatın bulunduğunun söylenmes ${ }^{59}$ de bu duruma imkân vermektedir.

Câhız, mûcizenin Allah'ın doğrudan fiili olduğunu vurgular. Çünkü kümûn-zuhûra göre âlem ve içindekiler tek bir anda Allah tarafından yaratılırken insanlar için aslah kabul edilen mûcize peygamberin elinde gerçekleştiği anda doğrudan yaratılmıştır. Ona göre Allah'in iradesi ilmine bağlı olduğu için Allah'ın yaratmayı istemesi yaratması ile aynı anlama gelmektedir. O, Allah'ın kulları için en uygun ve faydalı olanı yaratacağı bilgisinin Allah'ta bulunduğunu ve Allah'ın yarattıklarının tümünün varlıkların faydasına olduğunu kabul eder. ${ }^{60} \mathrm{Bu}$ nedenle peygamberin iddiası esnasında gerçekleşen mûcize, Allah'ın en iyiye ilişkin bilgisinin ihtiyâri değil, zorunlu bir sonucudur.

Peygamberin iddiası esnasında Allah'ın doğrudan müdahalesiyle mûcizenin gerçekleşmesi, meydana gelen bu durumu Câhız'ın "Yeni bir yaratılış mı yoksa cismin içinde bilkuvve bulunan alt bileşenlerin bilfiil hale gelmesi mi?” şeklinde değerlendirdiği sorusunu gündeme geir. Bu sorunun cevabını Hayyât'tan yapılan aktarımda bulabilmek mümkündür: "Allah bu dünyada zıtların

54 Câhız, Kitâbü'l-Hayevân, 5/83.

55 Ebû Rîde, İbrâhîm b. Seyyâr en-Nazzâm, 115-116.

$56 \quad$ Hayyât, el-intisâr, 48.

57 Wolfson, Kelâm Felsefeleri, 435.

58 "Muhakkak ki Allah dünyayı tek bir defada (cümleten) yaratmıştır. O, peygamberlerin mûcizelerini, peygamberlerin elinde mûcizeler meydana geldiği anda Allah'ın yarattığını iddia etmiştir.” bk. Hayyât, el-İntisâr, 52.

59 Câhız, Kitâbüll-Hayevân, 5/11-40; Cengiz, Doğa ve Öznellik, 47.

60 Câhız, bu konuda hocası Nazzâm'ın aslah görüşünü benimsemiş gibi görünmektedir. “Nazzâm'a göre Allah'ın eşyayı yaratmayı isteyen yani irade eden olması demek yaratmanın bizzat kendisidir.” Bk. Eş‘arî, Makālât, 190. 
arasını ayırmıştır. Cevherleri (cisimleri) tekrar yaratmaksızın zıtları bir araya toplamıştır... Eşyayı tabiatında olandan uzaklaştırmak, eşyanın zayıf olduğuna ya da zayıf olan tabiatın ortaya çıkışına delildir. Eşyadan çıkan bu zayıf tabiat, cisimde mevcuttur. Bu durum onun orda bulunmasını sağlayan bir muhdise ihtiyaç hissettirdiği gibi onun meydana gelişi de ancak bir muhdisle gerçekleşir. Bir muhdis olmaksızın onun meydana gelişi imkânsızdır." 61

Câhız'ın fizik teorisine göre cisimlerde kuvvetli ve zayıf olan alt bileşenler dengede iken dış müdahaleyle denge hâlleri bozulur. Cisimdeki alt bileşenlerin güçlü olanları zayıf olanları bastırarak cismin tabiatına uygun bir biçimde cisimden dışarı çıkar. Zayıf olanlar ise hem cismin dışına çıkan alt bileşenlerin hem de cismin içinde yer alan diğer alt bileşenlerin baskısı altında kaldıkları için hiçbir şekilde cisimden dışarı çıkamaz. Cisimde bulunan ve baskı altında olduğu için cismin dışına hiçbir şekilde çıkamayan bu zayıf tabiatlar, "cismi tabiatında olandan uzaklaştırmak suretiyle ancak peygamberin elinde mûcize meydana geleceği esnada Allah tarafından doğrudan müdahaleyle" cismin dişına çıkarılır. Burada onun fizik teorisinde cismin tabiatıyla gerçekleşen fiillerin Allah'a ait dolaylı fiiller olduğu, mûcizenin ise peygamberin iddiası esnasında doğrudan yaratma şeklinde gerçekleştiğini gözden kaçırmamak gerekir. Gerçekleşen bu durum hem yeni bir tabiatın cisme eklenmediğine delil oluşturur hem de cisimdeki zayıf tabiatın veya baskı altında kaldığı ve engellendiği için çıkması ancak ilâhî müdahaleyle mümkün olanın Allah müdahale etmediği sürece hiçbir şekilde cismin dışına çıkamayacağını gösterir. Bu durumda mûcizeyle "yaratılmış olan nesnenin içinde tabiatıyla birlikte bulunan, fakat daha önce hiç müşâhede edilmeyen ve Allah'ın müdahalesi olmaksızın dışarı çıkması mümkün olmayan zayıf tabiatın, ilâhî müdahaleyle cismin dışına çıkarılması" kastedilir. Buna göre mûcize, daha önce cisimde mevcut olmayan yeni bir tabiatın yaratılması ya da cismin mevcut tabiatının değiştirilmesi değil, baskı altında bulunduğu için cisimden dışarı çıkması mümkün olmayan ve daha önce hiç rastlanmayan zayıf tabiatın, Allah'ın istisnai bir şekilde cisme doğrudan müdahalesiyle dışarı çıkışı yani yaygın olan genel kuralın dışındaki bir tabiatla cisme müdahale etmesi anlamına gelir.

\section{Câhız'ın Âdet Anlayışı ve Mûcize}

Mûcizenin meydana gelişinin öncesinde kurulu bir düzenin varlığının ispat edilmesi, bu düzeni bozan durumun ancak ilâhî müdahaleyle gerçekleştiğini ortaya koyma açısından son derece önemlidir. Bu nedenle Câhız, âlemdeki bütün varlıkların belli bir işlevi yerine getirmek üzere evrendeki düzene katılmak için yaratıldığını ve onların bir amacı olduğunu öne sürer. ${ }^{62} \mathrm{O}$, âlemdeki düzenlemenin Allah tarafından yaratıldığını ${ }^{63}$ söyleyerek bunu ifade ederken tedbir kelimesini kullanır: “فكان لله ذلك التدبير الذي لايبلغه العبادولو اجتمعواله (Bu tedbir yani düzenleme Allah'a aittir. $\mathrm{Bu}$, bir araya gelseler bile insanların yapamadığ türden bir tedbir yani düzenlemedir.)" ${ }^{4}$ O, yeryüzünün bütün varlıklar için uygun olacak şekilde yaratıldı̆̆ını ve bu düzen içinde hiçbir varlığın ihmal edilmediğini de ifade eder. Kitâbü'd-Delâil ve'l-itibar isimli eserinde Câhı, evreni gözetim altında tutanın, evrendeki düzeni ve devamlılı̆̆ı sağlayanın Allah olduğunu söyleyerek Allah'ın hikmetli

\footnotetext{
61 Hayyât, el-íntisâr, 47.

62 İlhan Kutluer, “Gâiyyet”, Türkiye Diyanet Vakfi İslâm Ansiklopedisi (İstanbul: TDV Yayınları, 1996), 13/292.

63 Ebû Osman Amr b. Bahr el-Câhız, ed-Delâil ve'l-ittibar ale'l-halk ve't-tedbir (Beyrut: Dâru'n-Nedveti'l-İslâmiyye, 1409/1988), 6-7.

64 Câhız, Kitâbül'-Hayevân, 4/89; 6/268.
} 
fiillerinden örnekler verir. ${ }^{65}$ Ona göre düzenlemenin mükemmel oluşuyla birlikte Allah'ın hikmetiyle gerçekleştirdiği tüm fiilleri, Allah'ın varlı̆̆ına delildir. ${ }^{66}$ Câhız, varlıkların oluşumunun tabiatından zorunlu olarak (bi ıztırârin mine't-tabîati) meydana geldiğinin öne sürülmesinin asla mümkün olmadığını söyler. ${ }^{67} \mathrm{O}$, Allah'ın demiri keskin, zehiri öldürücü, gıdayı devamlı ve yırtıcı hayvanı zıplayan tabiatında yaratmayı dilediğine, ilim ve hikmetiyle onları bu şekilde düzenlediğine işaret eder. ${ }^{68}$ Câhız, bunların tümünün bir yaratıcının eseri olduğunu, yaratıcının $\operatorname{kasd}_{1}(\mathrm{amac} 1)$ ve takdiriyle meydana geldiğini vurgular. ${ }^{69}$

Câhız, eşyanın meydana gelişini yaratıcının düzenlediğini, nesnelerde bulunan tabiatların Allah tarafından nesnelere yerleştirildiğini ve bu tabiatların Allah'ın gözetiminde olduğunu belirtir. O, nesnelerdeki tabiatların normal şartlarda ve olağan durumlarda herkes tarafından bilinen bir düzen içinde devam ettiğini, fakat bazen onun gidişatına engel olan bir durum sebebiyle mevcut düzeninden ayrılabileceğini de ifade eder. Ona göre nesnede belirleyici özelliğe sahip olan bu tabiatlar, Allah tarafından düzenlenmiş bir programla hareket eder ve gerektiğinde insanların genel olarak gördüğü işleyişten alıkonulur. Bu nedenle bu tabiatlar, işlevlerini yerine getirmede Allah'ın kudreti ve iradesine muhtaçtır. ${ }^{70}$ Câhız, Allah'ın âleme ve insanlara istisnai bir şekilde doğrudan müdahalede bulunabileceğini kabul eder ve bu durumun da Allah'a ait bir tedbir ve düzenleme olduğunu belirtir. 0 , farklı olan ve bilinmeyen tabiatın peygamberliğe kesin delil olmak üzere Allah'ın müdahalesiyle ortaya çıkışının da Allah'ın bir düzenlemesi yani tedbiri olduğunu şu sözleriyle ifade etmiştir: "فقد كان لله فيه وفيها تدبير وليجعل ذلك آية لأنبيائه وبرهانا لرسله duhakkak ki mûcizeyi resullerine delil ve nebilerine âyet kılmasinda Allah'in bir tedbir ve düzenlemesi vardır.)"71

Âlemdeki düzen ve devamlılı̆̆a dikkat çeken Câhız, bu durum için “âdet” kavramını kullanmayı tercih eder. O, mûcizeyi de insanların genel olarak gördüğü düzenli işleyişten veya âdetten çıan durum olarak tanımlar. ${ }^{72}$ Âlemdeki düzeni ve devamlılı̆̆ı ifade etmek üzere "âdet" kavramını

65 O, yeryüzündeki bütün insan, hayvan ve bitkiler için güneşin doğması, güneş ışıklarının sürekli yayılması ve güneşin batmasının faydalarından bahsederek bunların Allah'ın hikmetli fillerinden olduğunu söylemiştir. Yerin doğasındaki kuruluk ile taşların doğasındaki kuruluktan söz ederek yerin doğasındaki kuruluğun taştaki gibi fazla olması hâlinde canlıların yaşamasını sağlayan bitkilerin yeşeremeyeceğini, tarımın ve binaların yapılamayacağını ifade etmiştir. Kuzeyden ve güneyden esen rüzgârları, denizlerdeki suyun yükselip alçalmasını, anne rahmindeki çocuğun ve annenin durumunu, insanın beş duyu organı ve tüm vücudunun işlevlerini Allah tarafından kurulmuş olan bu düzene örnek olarak vermiştir. bk. Câhız, ed-Delâil ve'l-i'tibar, 6,7, 14, 15, 45, 46.

66 Câhız, Kitâbü'l-Hayevân, 2/110.

67 Câhız, ed-Delâil ve'l-i'tibar, 61.

68 Câhız, belli bir tabiatta yaratılmış, hikmetle düzenlenmiş ve delilin sahibine istidlâl edilmek üzere hazırlanmış olan bu kâinatın Allah'ın varlığına, yaratıcılı̆̆ına, iradesine delil olduğunu söyler. 0 , insanların bu durumun farkında olacaklarını da ifade eder. bk. Câhız, "Hucecü'n-nubuvve”, 3/239; a. mlf., Resâilü'l-Câhız: er-Resâilü'l-kelâmiyye, thk. Ali Ebû Mülhim, (Beyrut: Dâru ve Mektebetü'l-Hilâl, 1422/2002), 135.

69 Câhız, ed-Delâil ve'l-i'tibar, 61. Bu konuda insanın yeme ve uyuma fiillerini ve bunlara getirilen düzeni örnek veren Câhız, her insanın doğasında onları yapmayı gerektiren ve ona sevk eden bir muharrikin olduğunu söylemiştir. Ona göre açlık yemek yemeyi gerektiren bir durumdur. Çünkü bedenin yaşaması ve devamlılığı ona bağlıdır. bk. Câhız, ed-Delâil ve'l-i'tibar, 52.

70 Câhız, ed-Delâil ve'l-i'tibar, 61.

71 Câhız, Kitâbü'l-Hayevân, 4/80.

72 Câhız, Kitâbü'l-Hayevân, 4/82. 
Câhız'dan önce Nazzâm'ın kullandığına dair bilgi Josef van Ess tarafından verilmiștir. ${ }^{73}$ Fakat Nazzâm ile ilgili bilgilerin sınırlılı̆ıı ve ilk dönem kaynaklarına ulaşılamaması sebebiyle âdet kavramının karşıllğını açık bir şekilde Câhız'da görebilmek mümkündür. Öne sürdüğü fizik teorisinde Nazzâm'ın etkisinde kaldığı göze çarpan Câhız'ın sözünü ettiği “âdet” anlayışının, “Allah'ı âdeti” şeklindeki kullanımı sebebiyle Nazzâm'a ait olma ihtimali de oldukça yüksektir. Câhız, âlemdeki varlıkların değişimini kümûn-zuhûra göre izah etmiş, evrende Allah tarafindan kurulan ve insanların farkında olduğu düzeni de "âdet" kavramıyla ifade etmiştir. Buna göre âdet, bilgi sahibi insanların farkında olduğu, evrene ilişkin genel kuralları ve Allah tarafından kurulan düzeni ifade eder. ${ }^{74}$

\section{1. Âdet Türleri}

Câhız'ın düşünce sisteminde âdet kavramının özel bir yeri vardır. O, âdeti üç kısma ayırır: Birinci kısımda, âlemdeki genel işleyişe uygun olarak gerçekleşen ve tüm insanların bildiği kuralları "kāim veya yerleşik âdet" başlı̆̆ altında ele alır. ${ }^{75}$ ikincisinde, herkes tarafından bilinmeyen sadece bir bölgede yaşayan insanların bildiği, o bölge dışındaki insanların bilmediği âdete yer verir. Bunun "bölgesel âdet" olarak nitelenebilmesi mümkündür. ${ }^{76}$ Câhız'ın sözünü ettiği bu iki âdet, Allah'ın kudreti altında bulunan ve insanların güç yetiremediği türdendir. O, üçüncü kısımda ise insanlar tarafından oluşturulan ve toplumda gelenek olarak adlandırılan âdete değinir. ${ }^{77}$ Buna toplumsal âdet de denilebilir. O, âleme müdahalenin imkanını kâim ve bölgesel âdet ile açıklarken insana olan müdahaleyi toplumsal âdet konusu ile ilişkili bir şekilde ele almıştır. Câhız'ın âdet anlayışının izlerini daha sonraki dönemlerde Mu'tezilî âlimlerden Kādî Abdülcebbâr'ın âdet teorisinde görebilmek mümkündür. 0 da âdeti tıpkı Câhız gibi mûcize türleri anlayışına göre şekillendirmiştir. ${ }^{78}$

73 "Characteristically enough it was a Baghdadi like Kā "bî who relied on the concept of the coutume de Dieu like alNazzām he believed in the existence of natural qualities that determine the functioning of bodies and guarantee the preservation of the species." (Tıpkı Nazzâm gibi Ebu'l-Kāsım el-Kâ‘bî de Allah'ın âdeti kavramına dayanarak cisimlerin fiillerine karar veren ve türün devamını sağlayan tabiî niteliklerin var olduğuna inandı.) bk. Josef van Ess, "Mu'tazilah", 10/228.

74 Câhız, Kitâbü'l-Hayevân, 2/145.

75 Câhız, Kitâbü'l-Hayevân, 2/145.

76 Câhı, Kitâbü'l-Hayevân, 4/101-104.

77 Câhı, Kitâbü'l-Hayevân, 2/52; 4/75.

78 Kādî Abdülcebbâr, Câhız’n insanların bulundukları yere ve şartlara göre oluşturmuş olduğu bu âdet anlayışını benimsemiş ve kendi âdet teorisini oluştururken de bu âdet anlayışından hareket etmiştir. O, âdeti nesnelerle ve insanlarla ilgili olmak üzere ikiye ayırmış, insanlarla ilgili olanı ise toplumda Allah'ın ve insanların oluşturmuş olduğu âdet şeklinde iki kısımda ele almıştır. Kâdî Abdülcebbâr, nesnelerle ilgili âdeti kendi fizik teorisine dayalı olarak açıklamıştır. Toplumda Allah tarafından oluşturulan âdet anlayışı, Câhız'ın bölgesel âdet anlayışı ile benzerlik göstermektedir. İnsanların oluşturmuş olduğu âdet ise Câhız'ın toplumsal âdetine benzemektedir. Câhız, sarfenin insanın duygularına uygulandığını söylerken Kādî Abdülcebbâr, insanların fiziki fiillerine Allah'ın engel olabileceğini kabul etmiştir. bk. Kādî Abdülcebbâr, el-Muğnî, 15/24, 182-184, 188-189, 191, 194-195, 201, 203, 205, 225, 262-264, 266-267; a. mlf., el-Muğnî, 16/171, 175, 205, 219, 322-323; a. mlf., el-Muhît bi't-teklîf, 387; Kādî Abdülcebbâr, Nedensellik Kitabı Kitâbü't-Tevlîd min Kitâbi'l-Muğnî, trc. Osman Demir (İstanbul: Klasik Yayınları, 2015), 20-21, 23, 28, 31-32, 38-40, 52-53, 66-68, 80-81, 85, 87-88,90, 102, 125, 141-145, 147, 155,159, 181-183, 205, 231; Demir, Kelâmda Nedensellik, 189, 191-192; Tâî Muhammed Bâsil-Milkâvî, Âmâl-Sabbârînî, Muhammed Saîd, "Çağdaş Fizik ve Müslüman Kelâmcılar Açısından Sebeplilik Kavramı”, trc. Kübra Şenel, Kutadgubilig Felsefe ve Bilim Araştırmaları Dergisi 23 (Mart 2013), 226-227. 
Câhız, kāim âdette mûcizenin nesnenin tabiatındaki zayıf alt bileşenin doğrudan ilâhî müdahaleyle nesnenin dışına çıkarılmasıyla gerçekleştiğini, bölgesel âdette ise belli bir bölgede yaşayan insanlarda bilgisi bulunan âdetin Allah tarafından ihlâl edilmesiyle meydana geldiğini savunur. O, ilk iki âdet türünde vuku bulan mûcizelerin Allah'ın kudreti altında yer aldığını söyler. Toplumsal âdette mûcize ise insanların güdüleri ve bilgilerinin Allah tarafından engellenmesi veya unutturulmasıyla yani sarfeyle gerçekleşir. Bu nedenle Câhız'ın âdet anlayışı, kāim, bölgesel ve toplumsal olmak üzere üç başlık altında ele alınabilir. Câhız'ın âdet anlayışına geçmeden önce onun âdet türleri ve mûcize konusuyla ilişkili olarak ele aldığı ve bütün olguları izah etmede kullandığı mümkün ve mümteni` sınıflamasına bir göz atmak gerekecektir.

\subsection{Mümkün, Mümteni‘ ve Mûcize}

Câhız, mümkün ve mümteni' kavramlarını da âdet türleri ve mûcize konusuyla ilişkili olarak ele almış ve onlara kendine özgü anlamlar yüklemiştir. Ona göre âlemi inceleyen kişi, tabiatı ve âdeti bilmelidir. Câhız, yukarıda zikrettiği üç âdet türünde -mûcizeyi de kapsayacak şekildegerçekleşen bütün olguları, mümkün ve mümteni‘ olmak üzere ikiye ayırmıştır. 0 , insanların yapabildiği ve güçleri altındaki olguların "mümkün" olarak niteleneceğini söylerken insanların gücü altında yer almayan, sadece Allah'ın kudreti altında bulunan ve Allah tarafından yapilan tüm olgulara da mümteni' adını vermiștir. ${ }^{79}$

Câhız, insanların yapabildiği ve güçleri altında yer alan tüm durumları "mümkün" kavramıyla ifade eder. Ona göre mümkün, insanların devamlı bir şekilde yaptıkları yani tecrübeyle bilinenler ve çok nadir olarak gerçekleşenler şeklinde ikiye ayrılır. O, birinci kısımda tecrübeyle bilinen insanlara ait âdet ve geleneklerin bulunduğunu belirtir. İkinci kısımda ise, aklın gerçekleşmesini mümkün gördüğü, fakat gerçek hayatta çok az karşılaşılan durumların yer aldığını ifade eder. ${ }^{80}$ Ona göre her ikisi de insanların gücü altında bulunan türdendir.

Câhız, "mümteni" kavramını Allah'ın kudreti altında yer alan olgular için oluşturmuş ve "mümteni'"yi "imkânsız anlamında değil, bir illetten dolayı engellenmiş" mânasında kullandığını belirtmiştir. Ona göre "mümteni" yani "bir illet nedeniyle engellenmiş olanlar" ikiye ayrılır: Bunlardan birincisi "geçici yani giderilmesi mümkün olan bir illete sahip" olanlar, diğeri ise "kalıcı yani giderilmesi asla mümkün olmayan bir illeti" bulunduranlardır. Câhız, mümteni" kategorisindeki her iki durumun da güçlerinin altında bulunmadığı için insanların yapamadığını sadece Allah'ın kudreti altında bulunan olguları içerdiğini söyler. ${ }^{81}$ Ona göre mûcizeler, bu kategoride gerçekleşen fiillerdir. Biri geçici, diğeri kalıcı olmak üzere iki tür illetten söz eden Câhız, geçici illetin mümkün kategorisinde yer alan olguya iliştiğini, bu illeti taşımasıyla mümkün olanın mümteni‘ kategorisine girdiğini ve geçici illetin Allah tarafından kaldırılması hâlinde olgunun yine mümkün kategorisinde bulunacağını belirtir. Onun bu ifadesini şu şekilde açılayabilmek mümkündür: İnsanların yapabildiği türde ve güçleri altında yer alan yani mümkün kategorisinde bulunan bir duruma -toplumsal âdet konusunda değinileceği üzere- Allah

79 Câhız, Kitâbül-Hayevân, 3/373.

80 Câhız, Kitâbü'l-Hayevân, 3/373. İbn Hazm, deli ve geri zekâlı olan bir kişinin mantık kuralları dâhilinde konuşmasını bu duruma örnek olabileceğini söyler. bk. Ebû Muhammed Alî b. Ahmed b. Hazm el-Endelüsî, el-Fasl: Dinler ve Mezhepler Tarihi, trc. Halil İbrahim Bulut (İstanbul: TürkiyeYazma Eserler Kurumu Başkanlığı Yayınları, 2017), 2/208.

81 Câhı, Kitâbü'l-Hayevân, 3/373-374. 
müdahalede bulunduğunda insanlar, normal şartlarda yaptıklarını yapamazlar. Allah, müdahaleyi kaldırdığında insanlar normal hayatlarına ve yaşantılarına geri dönerler. Buna Arapların Allah tarafindan Kur'an'a muâraza etmeye teşebbüs etmekten engellenmelerini yani sarfeyi örnek veren Câhız, bu kategoride gerçekleşen mûcizelerin insanların yapabildiği türden ve güçleri altında bulunduğunu fakat Allah'ın insanlara müdahalesi neticesinde eylemlerinden ve duygularından engellenmeleri nedeniyle yapamadıklarını belirtir. O, giderilmesi mümkün olmayan kalıcı illetin iliştiği olgunun Allah'ın kudreti altında yer aldığını ve insanların yapamadığı türden olduğunu ifade eder. Bu duruma Allah'ın cisme veya nesneye müdahalede bulunmasını örnek verir. Ona göre nesnede bulunan bilinmedik ve zayıf tabiatın Allah'ın müdahale etmesiyle nesnenin dışına çıkışı-kalıcı illeti bulunduran- bir mûcizedir.

Câhız, varlıkların tabiatının bilinmesinin ancak mümkün ve mümteni'nin bilgisine vakıf olunmasıyla gerçekleşebileceğini söyler. Ona göre mümkün, insanlardan meydana gelmesi ihtimal dâhilinde olandır. Onun muhal ile mümteni' arasındaki farkı açıklarken ${ }^{82}$ mümteni'nin meydana gelişinin insanlar için imkânsız olduğunu söylemesi, peygamberlerin elinde gerçekleşen mûcizeyi açılar mahiyettedir..$^{83}$ O, mûcizeleri ölüleri diriltme gibi kalıcı illete sahip ve Kur'an örneğinde olduğu gibi geçici illeti bulunduran şeklinde ikili bir ayrıma tabi tutmuş ${ }^{84}$, geçici ve kalıcı illetin insanların gücü altında olmadığını, sadece Allah'ın kudreti altında yer aldığını söylemiştir. Ona göre geçici ve kalıcı illeti kaldırabilecek tek varlık Allah'tır. Câhız'ın yapmış olduğu bu ikili tasnif, Mu'tezile'de Allah'ın kudreti altında bulunanlar ve insanların yapabildiği türden olanlar şeklinde mûcize sınıflamasını da açıklar niteliktedir. ${ }^{85}$

\subsection{Kāim (Yerleşik) Âdet ve Mûcize}

Câhız, birinci türdeki âdetin herkesin alışkın olduğu ve bildiği bir düzen olup insanların genel olarak gördüğü işleyişe göre oluşan genel kuralları ifade etmede kullanılan "kāim veya yerleşik âdet" olduğunu söylemiş, âlemdeki düzen ve devamlılı̆̆ bu kavramla açıklamıştır. O, "kāim âdet"in tanımını şu şekilde yapmıştır: "Kāim veya yerleşik âdet, güç ve imkâna sahip olanlar ile akıl ve marifet sahipleri nezdinde aşılması mümkün olmayan, kendisine itibar edilmesi gereken bir düzen, hiçbir şekilde kesintiye uğramayan ve hiçbir durumda düzensizliğin/karmaşanın mümkün olmadığı bir nizam (düzenleme)dır." "' Buna göre Câhız'ın "kāim âdet" şeklinde nitelediği, herkesin alışkın olduğu ve bildiği bir düzen yani insanların genel olarak gördüğü işleyişe göre oluşan genel kurallardır. $O$, Allah tarafından oluşturulan, devamlı olan, hiçbir şekilde kesintiye uğramayan ve düzensizliğin yaşanmadığı bu genel kuralların, bilgili ve akıllı insanlar tarafından fark edildiğini ve bilindiğini söylemiştir. Ona göre kāim âdetin aşılması ve insanlar tarafından bu düzenin bozulması mümkün değildir.

\footnotetext{
82 "Senin muhal ile mümteni" arasındaki farkı bilmen gerekir. Muhal, Allah'tan meydana gelmesi imkânsız olandır, mümteni ise yaratılmışlardan meydana gelmesi imkânsız olandır.” Câhız, Kitâbü'l-Hayevân, 3/374.

Câhız, Kitâbü'l-Hayevân, 3/373-374.

84 Câhız, "Hucecü'n-nubuvve", 3/229-230, 260.

85 Kādî Abdülcebbâr, mûcize türlerini yaratılmışların yapabildiği türden olanlar ve Allah'ın gücü altında bulunanlar şeklinde ikili tasnifle açıklamıştır. bk. Kādî Abdülcebbâr, el-Muğnî, 15/266; a.mlf., Şerhu'l-usûli'l-hamse, 569.

86 Câhız, Kitâbül-Hayevân, 2/145.
} 
Câhız’ın zikrettiği temelinde sebepliliği barındıran “kāim âdet”, Eş‘arî ve Kādî Abdülcebbâr'ın öne sürdüğü temelinde zorunsuzluğun yer aldığı âdet anlayışları gibi değildir. ${ }^{87} \mathrm{O}$, "kāim âdet" dediğinde Allah'ın sünnetini kastettiğini belirtir ve Allah'ın genel işleyişe uygun bir şekilde "sünnet"ini yarattığını ise şu şekilde ifade eder: "Cisimlerden meydana gelen bu fiillerin bir ilimden yoksun ve bir (muhdise) dayanmaksızın meydana geldiğini iddia edersen bu durum imkânsızdır. Çünkü yaratıcının fiilleri doğru ve hikmetlidir. Bu şekilde şunu bil ki bu fiiller, Allah'a aittir. Senin tabiat olarak isimlendirdiğin (bu fiiller), Allah'in sünnetidir (kanunudur). Onların meydana gelişi, Allah'in onları bu kanunlara uygun olarak yaratması nedeniyledir." ${ }^{88}$ Buna göre Câhız, Allah'ın yaratmasının insanların genel olarak gördüğü işleyiş̧e uygun genel kurallar şeklinde olduğunu ve "kāim âdet"in de Allah'ın sünneti anlamına geldiğini söyler. Câhız'ın zikrettiği âdet ise fizikîa âlemde Allah'ın sünneti olarak nitelenen insanların genel olarak gördüğü işleyişe uygun olan genel kurallar şeklindedir.

Câhız, insanların genel olarak gördüğü işleyişe bağlı olarak gerçekleşen kuralları ifade ederken mutlak anlamda bozulmayan veya hiçbir şekilde ihlâl edilmeyen anlamına gelen kelimeleri kullanmamış, "kāim âdet" kavramını yani "yerleşik âdet"i tercih etmiştir. Onun "kāim âdet" nitelemesiyle fizikî âlemde insanların genel olarak gördüğü düzenli işleyişe bağlı olarak gerçekleşen kuralların yani tabiat kanunlarının kastedildiğini söyleyebilmek mümkündür. Fakat onun kanun anlamına gelen kelimeleri değil de bu kavramı tercih etmesinin nedeni Allah'ın âlemin işleyişine müdahalesini yani mûcizenin meydana gelişini izah etmek için olabilir. Çünkü Câhız, "kāim âdet"e yönelik bilgi verirken onun akılll, marifet sahibi ve güçlü kişiler nezdinde bir değeri olduğundan bahsetmiş ve bu kişilerin nazarında mevcut düzeni, devamlı ve sürekli olan, kesintiye uğramayan, karmaşa ve düzensizliğin mümkün olmadığı şeklinde tanımlamıştır. Bu durum onun "kāim âdet"i, insanların genel olarak gördüğü işleyişe uygun bir şekilde oluşan genel kurallar şeklinde açıkladığını gösterir niteliktedir. ${ }^{89}$

Fiziksel bir kanunu ispat etmenin ötesinde evrendeki alışılmış düzen ve genel işleyişe dikkat çeken Câhız, tabiatın Allah tarafından düzenlenmiş ve insanlar tarafından fark edilen bir programa göre işlevini yerine getirdiğini ve Allah'ın gözetimi altında bulunduğunu söylemiştir. Ona göre bu tabiat, çok nadir durumlarda düzenlenmiş programından ve işlevinden ilâhî müdahaleyle alıkonularak insanların genel olarak gördüğü işleyişin dışına çıkarılabilir. o, bu durumun hem

87 Eş`arîâdet anlayışında arazların iki anda varlığını sürdürmesinin imkânsız olduğunun öne sürülmesi ile bütün nesne veya olgular her an yeniden yaratılmakta ve değişim arazların sürekli olarak yeniden yaratılması ile sağlanmaktadır. Tabiattaki süreklilik, sebep ve sonucun birbirine yaklaşması yani iktirân ya da bir arada görülmesi olarak ifade edilir. Onlara göre Allah, yaratmış olduğu ve insanlarda alışkanlık oluşturan âdete bağlı düzenini sadece peygamberin doğru sözlü olduğunun tesis edilmesinde gerekli olan mûcize için bozar. Eş‘arînnin âdet teorisinde Allah aklen imkânsız olan şeyleri de yapabilir ve bu durum sadece mûcize ile sınırlı değildir. Eş‘arîâlimlerden olan Bâkıllânî, yeryüzünde mevcut ve değişebilme özelliğine sahip âdete bağlı bir düzenin mevcudiyetini kabul eder. Mûcizeyi de bu âdete göre açıklar. bk. Kâdî Ebû Bekr Muhammed b. Tayyib el-Bâkıllânî, Kitâbü Temhîdil-evâil ve telhîsi'd-delâil, thk. İmâdüddîn Ahmed Haydar, Beyrut: Müessesetü'l-Kütübi's-Sekâfiyye, 1407/1986, 136; a. mlf., elBeyân, 50-55; Demir, Kelâmda Nedensellik, 159-160. Basra âdet teorisinde ise mûcize, peygamber gelmeden önce planlı bir şekilde insanlar içinde yaratılmış, devamlılığı sağlanmış ve bilgisi insanlarda zorunlu bulunan âdetin Allah tarafından nakzedilmesi ile gerçekleşir. O, Allah'ın ancak bir amaç için âdeti nakzedeceğini belirtir. Bu teoride âdet ancak mümküne imkân verir ve imkânsız sadece istisnai olan bir durumda yani mûcize de söz konusu olabilir. bk. Kādî Abdülcebbâr, el-Muğnî, 15/183; a. mlf., el-Muhît bi't-teklîf, 371.

88 Câhız, ed-Delâil ve'l-i'tibar, 43.

89 Câhız, Kitâbül'-Hayevân, 2/145. 
tabiatın düzenini sürdürmesi ve işlevini yerine getirmesinde Allah'ın iradesi ve kudretine muhtaç olduğunu gösterdiğini hem de fizikî âlemin ilâhî tasarrufa açık olduğu yani Allah'ın doğrudan yaratmasıyla işlevinden alıkonulduğunu sergilediğini belirtir. ${ }^{90}$ Câhız, insanların genel olarak gördüğg̈ işleyişe göre oluşan kuralları "نسق العادة" "âdetin düzenli oluşu” ifadesiyle verir ve Allah'ın gerektiğinde bu işleyişe müdahale edebileceğini, düzenli işleyişin değişebileceğini ve ilâhî müdahaleyle bu düzenin dışına çıkılabileceğini şu şekilde ifade eder: (كان ذالك البجئ خارجا من النسق (القائم والعادة المعروفة (Bu durum, kāim düzenden ve bilinen âdetten çıkarak meydana gelir. ${ }^{91} \mathrm{O}$, alışıا lmış âdet ve düzenli işleyişin dışına çıkılmasını da “نسق العادة" (âdetin düzenli oluşu)" kavramını kullanarak şu şekilde verir: “باشياء كثيرة خرجت خارجية من نسق العادة) (Genel işleyiş ve alışllmış düzenin kesin bir şekilde dışına çıkan birçok nesne vardır.)"92

Câhız, fizikî âlemde insanların genel olarak gördüğü işleyiş̧in gereği oluşan kuralların bozulmasını ya da farklı bir durumun ortaya çıkışını, tabiatın dışındaki bir durumun işin içine karışması olarak değil, bilinmedik veya farklı bir tabiatın dış müdahale sonucunda harekete geçip işlevsel hâle gelmesi şeklinde değerlendirir. Düzenli bir şekilde devam eden kurallar, onun tabiriyle âdet olarak nitelendiğinde bu genel kurallara Allah'ın müdahalesi nesnedeki farklı ya da zayıf tabiatın doğrudan yaratma yoluyla ortaya çıkışını sağlama şeklindedir. Burada Allah'ın genel işleyişe müdahalede bulunması tabiatı değiştirme şeklinde değil, yaygın olan genel kuralın dışındaki bir tabiatla duruma müdahale etmesi anlamındadır. Bu nedenle Câhız'a göre Allah'ın müdahalesi yani mûcize, tabiat dışı bir durumun işin içine girmesi değil, alışılmış düzen ve genel işleyişin dışına çıkaran, nesnedeki bilinmedik ve farklı bir tabiatın işlevsel hâle gelmesidir.

Câhız, "kāim âdet"te âlemdeki nesnelerle beraber hayvanlar ve insanların tabiatını da inceleme konusu yapmış, farklı olan ve bilinmeyen tabiatların onlarda da bulunduğunu söylemiştir. Ona göre bilinen tabiatlar, insanlar nezdinde kendisini dışa vuran ve tecrübe edilenlerdir. ${ }^{93}$ Câhız, mûcizenin de yaratıldığı ilk andan itibaren nesnede bulunduğunu fakat daha önce hiç tecrübe edilmediğini, insanlar tarafından görülmediğini ve bilinmediğini öne sürer. 0 , insanlar tarafından bilinmeyen ve tecrübe edilmeyen bu tabiatın, orada bulunmasını ve zamanı geldiğinde doğrudan ilâhî müdahaleyle mûcize olarak meydana gelmesini sağlayanın Allah olduğunu belirtir. Câhız, farklı olan ve bilinmeyen tabiatın peygamberliğe kesin delil olmak üzere Allah'ın müdahalesiyle ortaya çıkışının da Allah'ın bir düzenlemesi yani tedbiri olduğunu şu sözleriyle belirtmiştir: "Muhakkak ki Allah'in bunu (mûcizeyi) resullerine delil ve nebilerine âyet kllmasinda Allah'in bir tedbiri ve düzenlemesi vardır." ${ }^{94}$ Buna göre mûcize, istisnai bir şekilde nesnenin bilinen tabiatından uzaklaşması ve doğrudan ilâhî müdahaleyle bilinmeyen zayıf tabiatın ortaya çıkarılmasıdır. Bu bilinmeyen zayıf tabiatın Allah müdahalede bulunmadığı sürece nesnenin dışına çıkması asla mümkün değildir. ${ }^{95}$

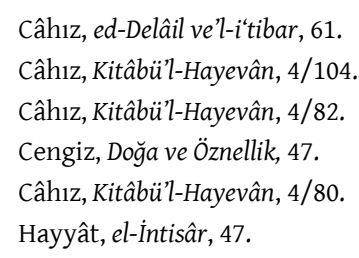


Câhız, âlemde herkesin bildiği genel kurallarda mûcizenin nesnedeki zayıf tabiatın ilâhî müdahaleyle ortaya çıkmasıyla gerçekleștiği söylemini nesnelerle sınırlı bırakmayarak hayvanlarda ve insanlarda da bu duruma örnekler bulunduğuna işaret eder ${ }^{96} \mathrm{O}$, olağan koşullarda bir insanın anne ve babasız dünyaya gelemeyeceğini fakat Hz. Îsâ'nın babasız olarak yaratılmasını ve Hz. Meryem'den dünyaya gelişini ${ }^{97}$; Hz. Havvâ ile Hz. Âdem'in bir baba ve anne olmaksızın yaratılmalarını; beşikte iken Hz. Îsâ'nın konuşmasını ${ }^{98}$; çocuk denecek yaşta Hz. Yahyâ'dan hikmetli sözlerin sâdır olmasıı ${ }^{99}$; Hz. Zekeriyyâ'nın karısı kısır olduğu hâlde çocuk sahibi olmasın $1^{100} ; \mathrm{Hz}$. İbrâhim ve karısının çok yaşlı olmalarına rağmen çocuk sahibi olmaların $1^{101}$ ve bir kuş olan hüdhüdün Hz. Süleyman'ın huzurunda konuşmasını ${ }^{102}$ insanların genel olarak gördüğü kuralları bozan ve alışılmış düzenin dışına çıkan olaylar olarak niteler ${ }^{103}$ ve bu durumun da Allah'ın bir tedbir ve düzenlemesi olduğunu belirtir. ${ }^{104}$ ìlâhî müdahaleyle gerçekleşen bu durumların peygamberlere kesin delil niteliğinde olduğunu ise şu sözleriyle dile getirir: "Hikmet sahibi olanın hikmetli işlerinden biri de her peygamberi, gönderilmiş olduğu halkı susturacak, onları cevap veremez hale getirecek şekilde hârikulâde işlerle yani mûcizelerle göndermesidir. Bunu da halkın düşüncesinde yer edinmiş olan eşyayı, alışılmış tabiatının dışına çıkararak yapar. ${ }^{105}$

\subsection{Bölgesel Âdet ve Mûcize}

Câhız’ın âlemdeki düzenli işleyişi açıklamada kullandığı ikinci türdeki âdet, bölgesel âdettir. Bölgesel âdete yöresel âdet te denilebilir. Bu âdet türü tüm insanlar tarafından değil, sadece bir beldede veya yörede yaşayan insanların bildiği ve bu beldenin dışına çıkıldığında diğer insanlar tarafından bilinmeyen âdettir. "Kāim âdet" herkes tarafından bilinirken "bölgesel âdet" sadece bir yörede yaşayan insanların bildiği türdendir. Câhız, "bölgesel âdet”e göçmen balık türlerinden biri olan, Dicle ve Basra kıyılarında görülen usbur balığını örnek verir. Bu balık göçmen bir balıktır

96 Câhız, Kitâbü'l-Hayevân, 4/82. Câhız'ın bu duruma vermiş olduğu örnekler için bk. a.mlf., Kitâbü'l-Hayevân, 4/77-93.

97 “(Meryem), "Ey Rabbim! Bana bir beşer dokunmamışken benim nasıl çocuğum olur?" dedi. Allah, "Öyle ama Allah dilediğini yaratır. O, bir şeyin olmasını dilediğinde ona sadece "ol" der, o da hemen oluverir" dedi." bk. Kur'an-Kerim Meâli, çev. Halil Altuntaş - Muzaffer Şahin (Ankara: Diyanet İşleri Başkanlığı Yayınları, 12. Basım, 2011), Âl-i İmran $3 / 47$.

98 “Bunun üzerine (Meryem, çocukla konuşun diye) ona işaret etti. 'Beşikteki bir bebekle nasıl konuşuruz?' dediler. Bebek şöyle konuştu: 'Şüphesiz ben Allah'ın kuluyum. Bana kitabı (İncil'i) verdi ve beni bir peygamber yaptı.” bk. Meryem 19/29-30.

99 “Biz, ona daha çocuk iken hikmet ve katımızdan kalp yumuşaklı̆̆ı ve ruh temizliği vermiştik." bk. Meryem 19/13.

100 "Zekeriyyâ'yı da an! Hani o, Rabbine şöyle niyaz etmişti: "Rabbim! Geride kalanların en hayırlısı sensin, yine de sen beni yalnız (çocuksuz) bırakma!" Biz onun da duasını kabul ettik ve ona Yahyâ’yı verdik; eşini de bunun için elverişli kıldık..." bk. Enbiyâ 21/89-90; "Zekeriyyâ. "Rabbim! Karım kısır olduğu, ben de ihtiyarlığın son sınırına vardığım halde, benim nasıl oğlum olabilir?" bk. Meryem 19/8.

101 “...Ben yaşlı bir kadın, şu da ihtiyar kocam; bu halde ben çocuk mu doğuracağım? Doğrusu bu şaşılacak bir şey!” dedi." bk. Hûd 11/72; Hicr 15/51-53.

102 "Derken Hüdhüd çok beklemedi, çıkageldi ve (Süleyman'a) şöyle dedi: ‘Senin bilmediğin bir şey öğrendim. Sebe'den sana sağlam bir haber getirdim." bk. en-Neml 27/22. Câhız, kurdun konuştuğunu, karganın bilgi sahibi olduğunu ve Hüdhüd’ün bir ilme sahip olduğunu kabul etmeyen kimselere cevap olarak genel işleyişten çıkan durumları örnek göstermiştir. O, bu şekilde düzenin dışına çıkanların sayıca fazla olduğu bilgisini de vermiştir. bk. Câhız, Kitâbü’lHayevân, 4/82.

103 Câhız, “Hucecü'n-nubuvve”, 3/240; a.mlf., Kitâbü'l-Hayevân, 4/75-93.

104 Câhız, Kitâbül-Hayevân, 4/80.

105 Câhız, “Hucecü'n-nubuvve”, 3/280. 
ve senede sadece iki ay yani ekim ve kasım aylarında Umman Denizi'nde ve Basra kıyılarında görülür. Bu ayların dışında bu balığın Basra kıyılarında görülmesi mümkün değildir. 0 , bu yörenin insanlarının usbur balı̆̆ının geliş zamanı bilgisine sahip olduklarını ve onun geleceği iki ayı beklediklerini belirterek şu bilgileri verir: "Bu balık, onlara Kızldeniz'den (Zenc denizi) gelir, sadece Umman Denizi ile Kizıldeniz'de bilinirdi. Usbur, Basra ve Dicle'ye gittiğinde Kizldeniz'de bulunmaz, Kızıldeniz'de bulunduğunda da Basra ve Dicle kıyılarında bulunmazdı." Bu yörede yaşayan insanların zihninde bu bilginin oluşumunu sağlayanın Allah olduğunu belirten Câhız, bu durumun da Allah'ın bir tedbir ve düzeni olduğunu söyler. ${ }^{106}$

Allah tarafından bir bölgeye has olarak yapılan bu düzenlemeyi bölgesel âdet olarak niteleyen Câhız, mûcizenin bu yöredeki insanların bilgilerine ters düşecek şekilde âdetin ihlâl edilmesiyle meydana geldiğini öne sürer. Bu yörede peygamberlik iddiasında bulunan bir kişi, nübüvvetine delil olmak üzere usbur balığını o iki ayda getirme sözünü verse -yöredeki tüm insanlar bu aylarda balığı avlayabilecekleri ve getirebilecekleri için- bu kişinin balık getirme iddiası dikkate alınmaz. Bu nedenle Câhız, bu balığı her hafta cuma günü mûcize olarak getireceğini söyleyen ve nübüvvet iddiasında bulunan kişinin dediğini düzenli bir şekilde gerçekleştirmesinin peygamberliğine delil olacağını söyler ve durumun delil oluşunu bu yörenin insanlarında balığın geliş zamanı bilgisinin bulunmasına bağlar. Çünkü usbur balığının her hafta cuma günü iddiada bulunan kişi tarafından getirilmesini ancak Allah sağlayabilir. ${ }^{107}$

Câhız, yöre halkında bilgisi bulunan bölgesel âdeti ihlâl ederek gerçekleşen her bir fiilin, bilinen âdet veya kurulu düzenden çıan bir olgu oluşunu ise şöyle ifade eder: "Bu şekilde nübüvvet iddiasında bulunan kişinin gerçekleştirdiği bu eylem ya da fiil, kurulu düzen ve alışlmış (bilinen) âdetten çıkan bir durum olur." Câhız, bölgesel âdetin ihlâl edilmesine kaynak, göl ve nehir suyu kenarında yaşayan kimselere nübüvvet iddiasında bulunan birinin "Ben her cumartesi iki balina getireceğim." demesini de örnek olarak verir. Ona göre peygamberlik iddiasında bulunanın söylediğini düzenli bir şekilde yapması, Allah'ın birliğine delil olduğu gibi iddiada bulunanın ve haberi veren kimsenin doğru sözlü olduğunu ve bölgedeki insanlar için peygamber seçildiğini de gösterir. Bölgesel âdet konusunda Câhız, bölge insanlarına özgü genel kurallar ya da düzenin bilgisinin o yörenin halkında mevcut olduğunu, bu nedenle düzeni ihlâl eden durumun diğer bölgelerde yaşayan insanlar tarafından değil, sadece o yörenin sâkinleri tarafından anlaşlabileceğini belirtir. ${ }^{108}$

\subsection{Toplumsal Âdet ve Mûcize}

Câhız, âlemdeki düzeni ve devamlılığı kāim ve bölgesel âdet türüyle ifade ederken hayat tarzları ve yaşantılarına göre insanlar tarafından oluşturulan düzen için "gelenek" ya da "âdet"i kullanır. Câhız, bu âdet türü ile insanların yapabildiği türde gerçekleșen mûcizeyi açıklar. O, insanların ortaya koydukları âdetin yaşadıkları yer ve bölgeye göre şekillendiğini, insanlar tarafından toplumun âdeti şeklinde kabullenildiğini savunur. Câhız, insanların dili kullanma biçimleri ve ölçülerine göre oluşan âdeti örnek verir ve bu durumu köle ile sahibi arasında geçen bir diyalogla açıklamaya çalışır. Sahibi, kölesine "Bana şu parayla et satın al!" dediğinde et sınıfına koyun, inek,

106 Câhı, Kitâbü̉l-Hayevân, 4/101-104.

107 Câhı, Kitâbü'l-Hayevân, 4/101-104.

108 Câhı, Kitâbü'l-Hayevân, 4/104. 
balık ve dana eti de girer fakat köle, et istediğinde sahibinin hangi eti istediğini veya kastettiğini bildiği için eti ona göre alır. Câhız, bu durumun insanların kendi hayat tarzları ve yaşantılarına uygun bir şekilde oluşan âdete örnek teşkil ettiğini belirtir. Ona göre bu bölgede yaşayan insanlar, "Et yedim." dediğinde de balık, kelle veya but yese bile et yemiş olarak kabul edilir. ${ }^{109}$ Buna göre insanlar, lafızların kullanılma biçim ve ölçülerini oluşturarak dildeki kurallarını belirlerler. Câhız'a göre yaşadıkları yörede insanlar tarafından oluşturulan bu âdet, o kişilerin aşina olduğu ve alıştığı bir düzendir. 0 , bizim âdetimize veya toplumun âdetine göre denildiğinde toplum yaygınlıkla bu şekilde yapar şeklinde anlaşılması gerektiğini söyler. ${ }^{110}$ Fakat bu âdet, sadece o yörenin insanlarına ait olup o bölgede geçerlidir. Bölgenin dışına çıkıldığında konulan kurallar, toplum veya bölgeye göre değişkenlik gösterebilir.

Bir toplum veya bölgede oluşturulmuş genel kurallardaki âdete toplumsal âdet denilebilmesi mümkündür. Câhız'a göre toplumsal âdette mûcize, Allah'ın insanlara müdahalesi yani sarfe ile gerçekleşir. ${ }^{111} \mathrm{O}$, sarfe ile Allah'ın insanlara müdahalede bulunmasını kastetmiş ve sarfenin niyetlerinden alıkonulma, yapacakları işten engellenme veya bilgilerini ya da bildiklerini unutma şeklinde meydana geldiğini söylemiştir. ${ }^{112}$ İnsanların yapabildiği türdeki mûcizenin Kur'an olduğunu belirten Câhız, onun mûcize oluşunu da sarfe ile açıklamıştır. O, Allah'ın insanlara müdahalesinin mümkün olduğunu göstermek için Kur'an'dan bazı örnekleri de delil olarak kullanmıştır. Ona göre Tih çölünden İsrailoğulları'nın kırk sene boyunca çıkamamalarr ${ }^{113}$, güç kuvvet sahibi Hz. Süleymân'ın kendisine çok uzak olmayan Sebe kenti ve kraliçe Belkıs'ı bilmemesi ${ }^{114}, \mathrm{~Hz}$. Süleyman'ı öldüğünü etrafında bulunan cin ve insanların idrak edememeleri ${ }^{115}$, Mısır'da üstün bir mevkiye sahip olan Hz. Yusuf'un babasını arama isteğinin içinde

109 Câhı, Kitâbü'l-Hayevân, 4/75-76.

110 “Bizim âdetimize veya bizdeki âdete göre eşeğin kargaya olan düşmanlığı devamlıdır." Bu sözü söyleyenin kim olduğunu bilmediğini belirten Câhız, durumun uzun süre boyunca böyle olduğunu “âdet” kavramı ile ifade etmiştir. bk. Câhız, Kitâbü'l-Hayevân, 2/52.

111 ، فانا نقول بالصرفة في عامة هذه الأصول وفي هذه الأبواب (Biz bunun bu usul ve esaslarda genelde sarfe ile olduğunu söylüyoruz.)” bk. Câhız, Kitâbü'l-Hayevân, 6/268.

112 Fahreddin er-Râzî, Nihâyetü'l-îcâz, 26. Câhız, bu durumu Kitâbü'l-Hayevân adlı eserinde şu şekilde ifade eder: “Bu durumun bir benzeri de Araplardan evhamın (düşüncenin) alınmasıyladır. Hz. Peygamber'in Kur'an'in nazmıyla Araplara meydan okumasından sonra Allah onların nefislerini Kuran'a muârazadan engellemiştir. Bu nedenle bu konuda çok istekli hiç kimseye de rastlanmamıştır." bk. Câhız, Kitâbü'l-Hayevân, IV, 89. Maverdî, en-Nüket ve'l-uyûn adlı eserinde sarfe teorisini benimseyenleri ikiye ayırır: Birinci görüşte Kur'an'la meydan okunduğunda tehaddîye muhatap olanların, Kur'an'a muâraza etme teşebbüsünden (dürtü ve düşüncelerinden) Allah tarafından alıkonulduğunu savunulur. Bu görüşü benimseyenler, tehaddîye muhatap olan kimselerin Kur'an'ın benzeri bir metni yapma dürtülerinden alıkonulmamış olsalar bile bu tarz bir fiili yapmaktan âciz kalınacağını öne sürerler. İkinci görüşte meydan okunan kişilerin Kur'an'a muâraza etme imkân ve gücüne sahip oldukları, bu nedenle Allah tarafindan bu fiili gerçekleştirmelerinin engellendiği kabul edilir. Bu görüşü savunanlar, tehaddîye muhatap olanların engellenmedikleri takdirde Kur'an benzeri bir metni ortaya koyacaklarını iddia ederler. bk. Mâverdî, en-Nüket, 1/33. Mâverdî’nin vermiş olduğu bu malumata göre birinci görüşü Câhız, ikinci görüşü Nazzâm savunur. Çünkü Hillî, Menâhic isimli eserinde Nazzâm'ın ikinci görüşü benimsediğini açık bir şekilde ifade etmiştir. O, Nazzâm'ın Kur'an'ın mûcize oluşunu, insanların doğal olarak yaptıklarından Allah tarafından alıkonulmalarıyla açıkladığını belirtir. bk. Hillî, Menâhic, 276.

113 Câhı, Kitâbü'l-Hayevân, 4/86-87; 6/268.

114 Câhı, Kitâbü'l-Hayevân, 4/85-86; 6/269.

115 Câhı, Kitâbü'l-Hayevân, 6/269. 
bulunmamas ${ }^{116}, \mathrm{~Hz}$. Peygamber'in ashabının zihninde Bedir Savaşı'nda Allah tarafından yapılan yardımın diğer savaşlarda da yapılacağı beklentisinin olmayışı ${ }^{117}$ ve Arapların Kur'an'ın benzeri bir metni ortaya koyma istek ve arzusunun onlardan alınmas $1^{118}$, insanlara ilâhî müdahalenin gerçekleştiğine yani Allah tarafından insanlara sarfenin uygulandığına örnek oluşturur. Ona göre bu örnekler, Allah'ın insanlara ve toplumlara müdahalesinin de Allah'a ait bir tedbir ve düzenleme olduğunu ortaya koyar. ${ }^{119}$ Câhız’n sarfenin uygulandığını göstermek üzere öne sürdüğü bu örneklerin hocası Nazzâm'a ait olması ihtimal dâhilindedir. ${ }^{120}$

Câhız'ın sarfenin uygulandığına dair Kur'an'dan almış olduğu örneklerden ilki, kırk sene boyunca Tih çölünde kalan ve bir türlü çıkış yolunu bulamayan Benî İsrâil'in durumudur. ${ }^{121} \mathrm{O}$, Benî İsrail'in Tih çölüyle ilgili bilgilerinin Allah tarafından alındığını ve Allah'ın onlara müdahalede bulunarak bu bilgileri unutturduğunu şu sözleriyle dile getirir: "Onlar, kırk sene hep o çölde kalmış ve yanlış yollara saparak çıkış yolunu bir türlü bulamamışlardı. Hâlbuki onlar, Tih Çölü’nde sadece dinlenme molası vermiş ve bir süreliğine konaklamışlardı. Hz. Mûsâ ile birlikte yer ve yurt edinmek amaciyla memleketleri Mısır'dan yola çımıışlardı. Onların içinde ticaret yapan tüccarlar, kervanlara rehberlik edenler, hükümdarlara haber getirip götüren elçiler, ücretli çalsşıp yol bulan ve bu yolları avucunun içi gibi bilen izciler vardı. Fakat onlar, (içlerinde bunca bilgili kişi bulunmasına rağmen) Tih Çölü’nde yaklaşık 40 yıl kaldılar ve bir türlü çıııs yolunu bulamadılar."122

Câhız, Mısır hükümdarının veziri olan Hz. Yusuf'un güce, kuvvete ve şöhrete kavuşmasına rağmen babası Hz. Ya'kūp'u arama isteğinin içinde oluşmamasını da Allah tarafından bu güdüden alıkonulması şeklinde açıklamıştır. ${ }^{123}$ O, Bedir Savaşı'nda Allah'ın meleklerle Müslümanlara yardım ettiğini söylemişs ${ }^{124}$, zor zamanlarında veya savaşlarda kendilerine yardım edileceği beklentisinin Müslümanlarda bulunmamasını da sarfe yani ilâhî müdahale ile olduğunu ifade

116 Câhız, Kitâbü'l-Hayevân, 4/86; 6/269.

117 Câhız, Kitâbü'l-Hayevân, 4/88-89; 6/269.

118 Câhız, Kitâbül'-Hayevân, 4/89; 6/269.

119 Câhız, Kitâbül'-Hayevân, 4/89; 6/268.

120 Richard C. Martin, Câhız'nn öne sürdüğü sarfeye dair örneklerin Nazzâm'a ait olduğunu söylemiştir. bk. Richard Carleton Martin, A Mu'tazilite Treatise on Prophethod and Miracle: Being Probably the bâb alâl-Nubuvvah from the Ziyâdat al-sharh by Ebû Rashid al-Nîsâbûrî (Died First Half of the Fifty Century A. H.) (Michigan: New York University, Doktora Tezi/Ph. D. Dissertation, 1975), 88-89.

121 “Dediler ki: 'Ey Mûsâ! Onlar orada bulundukça, biz oraya asla girmeyeceğiz. Sen ve Rabbin gidin, onlarla savaşın. Biz burada oturacağız.' Mûsâ, 'Ey Rabbim! Ben ancak kendime ve kardeşime söz geçirebilirim. Artık bizimle, o yoldan çıkmışların arasını ayır' dedi. Allah, şöyle dedi: 'O hâlde, orası onlara kırk yıl haram kılınmıştır. Bu süre içinde yeryüzünde şaşkın şaşkın dönüp dolaşacaklar. Artık böyle yoldan çıkmış kavme üzülme!” bk. Mâide 5/23-26.

122 Câhız, Kitâbü'l-Hayevân, 4/86-87.

123 Câhız, Kitâbü'l-Hayevân, 4/86; 6/269; Bilge, “Ebû İshâk İbrâhîm b. Seyyâr en-Nazzâm'ın Mûcize Anlayışı: Nazzâm'ın Tabiat Teorisi Çerçevesinde Bir İnceleme”, 609-610.

124 Âl-i İmrân 3/122-126. Câhız, meleklerin bilfiil savaşa katılmadıklarını, savaşın zorluğunu üstlenmeleri nedeniyle sadece ashabın içindeki korkuyu ve evhamlı hallerini onlardan almak için indiklerini söyler. bk. Câhız, Kitâbü'lHayevân, 4/88-89. 
etmiş̧ir. ${ }^{125}$ Arapların Kur'an'a muâraza edememeleri de sarfe nedeniyledir. ${ }^{126}$ Ona göre Kur'an'ın nazmıla meydan okunduğunda tehaddîye muhatap olanlar, Allah tarafından Kur'an'a muârazaya teşebbüs etmekten engellenmiş ve sarfe gerçekleşmiştir. ${ }^{127} \mathrm{O}$, bu durumu şu sözleriyle ifade eder: "Araplardan evhamin alinmasinin bir benzeri de Hz. Peygamber'in onlara Kur'an'in nazmiyla meydan okumasindan sonra onların nefislerinin (Allah tarafindan) Kur'an'a muârazadan sarf edilmeleri/ engellenmeleridir. Bu nedenle biz, bu konuda onu yapmaya çok istekli olan hiç kimseyi görmedik. Eğer onlar bu konuda hırslı olsalardı, ona muâraza etme sorumluluğunu üstlenirlerdi. Eğer onlardan bazıları bu sorumluluğu üstlenselerdi, Kur'an nazmına șüpheyle bakmayı gerektirecek metinlerini derhal ortaya koyarlar ve böyle bir metin Arap ve Arap olmayanlar arasinda hızlica yayginlaşırdı. Dahası bu durumu Müslümanların önüne delil olarak koyarlar ve iki metin arasında hüküm verilmesini talep ederler, söylentiler de yayllir giderdi. ${ }^{\prime 28}$

Câhız, Hz. Süleyman'ın Sebe halkından ve kraliçesi Belkıs'tan haberinin olmamasını da sarfeyle açıklar. Hz. Süleyman'ın güçlü bir hükümdar olması sebebiyle kendisine çok uzak olmayan bu ülkeyi bilmemesinin imkânsız olduğunu fakat Allah'ın düzenlemesi ve tedbiri sonucunda bu ülkeden haberinin olmadığını belirtir. ${ }^{129}$ Câhız'ın bu konuda son örneği ise Hz. Süleyman'ın asasına dayalı bir şekilde vefat etmesine ve bu şekilde uzun süre kalmasına rağmen onun emrinde çalışan cin, şeytan ve insanların ${ }^{130}$ onun öldüğünü anlayamamalarıdır. ${ }^{131}$ Onlar, Hz. Süleyman'ın hiç kıpırdamadan saatlerce kalmasından bile şüphe etmemişler ve vesveseye kapılmamışlardır. ${ }^{132}$ Ona göre ilâhî bir engelleme olmasaydı, oradakilerin tümü aynı düşünceyi paylaşmaz, içlerinden birisi mutlaka onun durumundan şüphelenirdi. Câhız, neden bu şekilde düşündüğünü ise şu şekilde izah eder: "Allah'in dilediği kişinin zihnine attığı engelleyici düşünceler olmasaydı ve Allah, zihinleri dilediği şekilde meşgul etmeye, dilediğini hatırlatmaya, dilediğini unutturmaya muktedir olmasaydı, Hz. Süleyman'in emrinde hizmetçi olarak çalışan cinler, şeytanlar ve dünya ehlinin tamamı bu engellemeler sonucunda onun canlı olduğuna dair ittifak halinde olmazlardı. Onların içlerinden biri mutlaka Hz. Süleyman'in durumundan şüphelenirdi." ${ }^{133}$

125 Câhız, meleklerin yardım edeceği ve zafer müjdesini Hz. Peygamber'in ashabına Allah'tan gelen vahiyle bildirdiğini söyler. Eğer Müslümanlar, her savaşta veya zor durumda bu müjdeyi hatırlamış olsalardı, bize yardım edilecek düşüncesiyle hareket eder ve gevşek davranırlardı. Hâlbuki onlar, öldürülüp öldürülmeyeceklerini veya savaşı kazanıp kazanamayacaklarını bilmeden savaşma ruhuyla hareket etmişlerdir. Ona göre bu durum, ilâhî yardım beklentisinin onlardan alındığına delilidir. bk. Câhız, Kitâbü'l-Hayevân, 4/88-89.

126 Câhız, Kitâbü'l-Hayevân, 4/89.

127 O, Kur'an'a muâraza etmeye teşebbüs etme güdülerinin onlardan alındığını veya bu işten engellendiklerini düşünür. Çünkü ona göre Arapların tabiatı, muârazayı terk edip başka durumlara yönelmelerine izin vermez. Bu konuda kendisine onların muâraza etme güçleri bulunduğunu, fakat muârazayı terk etmeyi tercih ettiklerini savunanların olduğunu ifade eden Câhız, tehaddîye muhatap olanların içlerinde bir sürü akıllı, zeki, hatip, şairin bulunmasına ve her birinin muâraza etme sebebine sahip olmasına rağmen muârazanın meydana gelmediğine dikkat çeker. bk. Câhız, Resâilü'l-kelâmiyye, 154-155.

128 Câhız, Kitâbü'l-Hayevân, 4/89.

129 Câhız, Kitâbü'l-Hayevân, 4/85-86.

130 el-Enbiya, 21/82; Sebe', 34/12-15.

131 Câhı, Kitâbü'l-Hayevân, 4/91.

132 Câhı, Kitâbü'l-Hayevân, 4/90.

133 Câhız, Kitâbü'l-Hayevân, 4/92; Bilge, “Ebû İshâk İbrâhîm b. Seyyâr en-Nazzâm'ın Mûcize Anlayışı: Nazzâm'ın Tabiat Teorisi Çerçevesinde Bir İnceleme”, 609-610. 
Câhız, toplumda insanlar tarafından oluşturulan âdet veya genel kurallara yani toplumsal âdete Allah'ın müdahale edebileceğini ve bu müdahalenin de Allah'ın tedbiri yani düzenlemesi olduğunu belirtmiştir. ${ }^{134}$

\section{Sonuç}

Câhız'ın mûcize anlayışının ele alındığı bu çalışmada onun âdet teorisi ve mûcize görüşüne yer verilmiştir. Onun genel Mu'tezilî düşüncede yer alan mûcize türleri ile ilgili Allah'ın kudreti altında ve insanların yapabildiği türden olmak üzere yapmış olduğu sistematik sınıflama daha sonraki dönemlerde diğer Mu'tezilî âlimler tarafından da kullanılmıştır. Câhız, âdet teorisini de bu sinıflamaya göre oluşturmuş, "kāim âdet" ve "bölgesel âdet"in Allah'ın kudreti altında yer aldığını, "toplumsal âdet"in ise insanların yapabildiği türden olduğunu söylemiştir. Onun fiil türüne göre yapmış olduğu bu tasnif, mûcize anlayışına da yansımış ve mûcizeyi Allah'ın âleme ve insana müdahalesi şeklinde iki türlü ele almıştır. Câhız, Allah'ın âleme müdahalesini Allah-âlem ilişkisi ekseninde tabiat teorisine dayalı olarak açıklamış, insana müdahalesini ise insan fiilleriyle ilişkili olarak değerlendirmiştir.

Câhız, mûcize öncesinde bir düzenin mevcudiyetine dikkat çekmiş ve bu düzenin de Allah ve insanlar tarafından kurulduğunu öne sürmüş, bu düzeni âdet kavramıyla ifade etmiştir. Mûcizeyi de içerecek şekilde evrende meydana gelen bütün olguları mümkün ve mümteni` olmak üzere ikiye ayırmıştır. Bu sınıflama tamamen Câhız'a özgüdür ve o, bunu mûcizeyi izah etmekte kullanmıştır. Câhız, insanların gücü altındaki olgulara mümkün adını vermiş, mûcizenin ise mümteni` kategorisinde meydana geldiğini öne sürmüştür. Ona göre mümteni` imkânsız değil, bir illetle engellenmiş anlamına gelir. O, Allah'ın kudreti altında bulunan mûcizelerin kalıcı illete sahip olduğunu, insanların gücü altındaki fiillerin ise geçici illeti barındırmasıyla mûcize olduğunu söyler. Ona göre her ikisindeki illeti ancak Allah kaldırabilir. Onun geçici illet olarak nitelediği durum, mümkün kategorisinde insanların gücü altında yer alanlara Allah'ın müdahalesi anlamına gelen sarfeyle oluşur.

Onun âdet anlayışının mûcize türlerine göre şekillendiğini söyleyebilmek mümkündür. $\mathrm{Bu}$ nedenle o, âdeti "kāim, bölgesel ve toplumsal" olmak üzere üç kısma ayırmıştır. Ona göre "kāim âdet", kümûn-zuhûra dayalı olan ve âlemde insanların genel olarak gördüğü düzenli işleyişin gereği oluşan kurallardır. Âlemde Allah tarafından oluşturulmuş olan, herkesin bildiği ve fark ettiği bu düzenli işleyişi o, ilâhî düzenleme anlamına gelen "tedbîr" kavramıyla ifade etmiş ve "kāim âdet"in nesnelere konulan tabiat aracıllğıyla düzenli bir şekilde devam ettiğini söylemiştir. Allah'ın âleme müdahalesi olan mûcize ise insanların genel olarak gördüğü düzenli bir şekilde devam eden "kāim âdet"in dışına çıkılmasıyla yani bilinmedik zayıf tabiatın Allah tarafından işlevsel hâle getirilmesiyle gerçekleşir. İkincisi, herkes tarafından bilinmeyen sadece belli bir bölgede yaşayan insanların bildiği "bölgesel âdet"tir. Câhız, bu âdet türünde mûcizenin belli bir bölgede yaşayan insanlarda bilgisi bulunan âdetin Allah tarafından ihlal edilmesiyle gerçekleştiğini belirtir. Üçüncüsü ise toplumsal âdet olarak nitelenebilen insanlar tarafından toplumda oluşturulmuş âdettir. Bu âdet türünde mûcize, sarfe ile yani Allah'ın insanların güdülerine veya bilgilerine müdahalesiyle meydana gelir. Câhız, insanlara sarfenin uygulandığına

134 Câhız, Kitâbü'l-Hayevân, 4/89; 6/268-269. 
dair örneklerin Kur'an'da bulunduğunu söyler ve sarfenin mümkün olduğuna delil olarak bu örnekleri verir. O, kāim ve bölgesel âdet türünde mûcizenin Allah'in kudreti altında ve mümteni ${ }^{*}$ kategorisinde gerçekleştiğini söylerken toplumsal âdetin mümkün kategorisinde yer aldığını fakat insanlara sarfenin uygulanmasıyla meydana gelen mûcizenin mümteni' kategorisine girdiğini belirtir. Câhız, âlemdeki düzeni "tedbîr" kelimesi ile ifade ederken mûcizenin meydana gelişinin de Allah'ın bir tedbîri yani düzenlemesi olduğunu söylemiştir.

Câhız’ın mûcize anlayışının ve âdet teorisinin izlerini daha sonraki dönemlerde Mu'tezilî âlimler üzerinde görebilmek mümkündür. Kâdî Abdülcebbâr'ın âdet teorisinde Allah'in kudreti altındaki mûcizeler "genel âdet" ve "bölgesel âdet" ile izah edilmiş, insanların gücü altındaki mûcizeler ise "toplumsal âdet" şeklinde ele alınmıştır. Temeli farklı fizik teorisine dayanmasına rağmen Kādî Abdülcebbâr'ın âdet teorisinde Câhız'ın izleri açık bir şekilde görülebilir.

Öne sürdüğü âdet teorisi ve mûcize anlayışı ile kendisinden sonra gelen Mu'tezilî düşünürleri etkileyen Câhız’n mûcize türleri konusundaki sistematik ayrımı daha sonraki dönemlerde Mu'tezilî kelâmcılar tarafından da benimsenmiştir. O, âdet teorisini ortaya koyarken insanların gördüğü ve farkına vardığı düzenlemeye dikkatleri çekmiş ve âlemdeki düzenin insanların genel olarak gördüğü işleyişin gereği oluşan kurallar olduğunu söylemiştir. 


\section{Kaynakça}

Bâkıllânî, Kādî Ebû Bekr Muhammed b. Tayyib. Kitâbü'l-Beyân ani'l-fark beyne'l-mu'cizât ve'l-kerâmât ve'l-hiyel ve'l-kehâneti ve's-sihri ve'n-narencât. thk. Richard J. McCarty. Beyrut: el-Mektebetü'şŞarkıyye, 1377/1958.

Bâk1llânî, Kâdî Ebû Bekr Muhammed b. Tayyib. Kitâbü Temhîdi'l-evâil ve telhîsi'd-delâil. thk. İmâdüddîn Ahmed Haydar. Beyrut: Müessesetü'l-Kütübi's-Sekâfiyye, 1407/1986.

Baktır, Mehmet. "Câhız’ın Varlık ve Tabiat Anlayıșı". Cumhuriyet Üniversitesi İlahiyat Fakültesi Dergisi 10/2. 2006, 237-256.

Baktır, Mehmet. “Câhız'ın Nübüvvet Anlayışı”. Cumhuriyet Üniversitesi İlahiyat Fakültesi Dergisi 10/2. 2006, 257-268.

Bilge, Meliha. "Ebû İshak İbrâhîm b. Seyyâr en-Nazzâm'ın Mûcize Anlayışı: Nazzâm'ın Tabiat Teorisi Çerçevesinde Bir İnceleme”. KADER 18/2 (2020), 587-616.

Câbirî, Muhammed Âbid. Arap İslâm Kültürünün Akıl Yapısı. çev. Burhan Köroğlu-Hasan HacakEkrem Demirli. İstanbul: Kitabevi Yayınları, 2. Basım, 2000.

Câhız, Ebû Osman Amr b. Bahr. ed-Delâil ve'l-i'tibar ale'l-halk ve't-tedbir. Beyrut: Dâru'n-Nedveti'lİslâmiyye, 1409/1988.

Câhız, Ebû Osman Amr b. Bahr. Resâilü'l-Câhız: er-Resâilül'-Kelâmiyye. thk. Ali Ebû Mülhim. Beyrut: Dâru ve Mektebetü'l-Hilâl, 1422/2002.

Câhız, Ebû Osman Amr b. Bahr. Kitâbü'l-Hayevân. thk. Abdüsselâm Muhammed Hârûn. 7 Cilt. Kāhire: Mektebetu Mustafa el-Babi el-Halebi ve Evlâduhu, 2. Basım, 1385/1965.

Câhız, Ebû Osman Amr b. Bahr. "Hucecü'n-nubuvve”. Resâilü'l-Câhız. thk. Abdüsselâm Muhammed Hârûn. 3/223-281. Beyrut: Dâru'l-cîl, 1411/1991.

Cengiz, Yunus. Doğa ve Öznellik Câhız’in Ahlâk Düşüncesi. İstanbul: Klasik Yayınları, 2015.

Cengiz, Yunus. "Nazzâm'ın Düşüncesinde Tanr1, Doğa ve İnsan”. Doğudan Batıya Düşüncenin Serüveni: İslâm Düşüncesinin Altın Çağı. ed. Abdullah Kahraman. 5/573-604. İstanbul: İnsan Yayınları, 2015.

Cengiz, Yunus. "Câhız: Doğa Temelinde İnsan Üzerine Düşünmek”. Doğudan Batıya Düşüncenin Serüveni: İslâm Düşüncesinin Altın Çağı V. ed. Abdullah Kahraman. 5/543-572. İstanbul: İnsan Yayınları, 2015.

Demir, Osman. Kelâmda Nedensellik İlk Dönem Kelamcılarında Tabiat ve İnsan. İstanbul: Klasik Yayınları, 2015.

Ebu'l-Kāsım el-Kâ‘bî, Abdullah b. Ahmed b. Mahmûd el-Belhî. Kitâbü'l-Makālât ve meahu uyûnu'lmesâil ve'l-cevâbât. thk. Hüseyin Hansu - Râcih Kürdî - Abdülhamid Kürdî. İstanbul: Kuramer Amman: Dârü'l-Feth, 2018.

Erkan, Arif. Beyân. İstanbul: Yasin Yayınevi, 2006. 
Ess, Josef Van. “Abû Eshâq al-Nazzâm”. Encyclopedia Iranica. ed. Ehsan Yarshater. 1/275-280. London: Routledge and Kegan Paul, 1985.

Ess, Josef Van. “Ebû İshak en-Nazzâm Örneği Üzerinden Kelâm-Bilim İlişkisi”. çev. Mehmet Bulğen. Marmara Üniversitesi İlahiyat Fakültesi Dergisi 46 (Nisan 2014), 267-286.

Ess, Josef Van. “Mu'tazilah”. The Encyclopedia of Religion. ed. Mircea Eliade. 10/220-229. New York: Macmillan Publishing Company, 1987.

Eş'arî, Ebü'l-Hasan Alî b.İsmail. Makālâtü'l-İslâmiyyîn ve'htilâfü'l-musallîn. nşr. Helmut Ritter. Weisbaden: Franz Steiner Verlag, 1400/1980.

Fahreddin er-Râzî, Muhammed b. Ömer b. el-Hüseyin. Nihâyetü'l-iccâz fî rivâyeti'l'-icâzz. thk. Nasreddin Hacımüftüoğlu. Beyrut: Dâru Sâdır, 2004.

Hayyât, Ebü'l-Hüseyin Abdürrahim b. Muhammed b. Osman. Kitâbüll-İntisâr ve'r-red âlâ İlon Râvendî el-mülhid. thk. H. S. Nyberg. Beyrut: Mektebetü'd-Dâri'l-Arabiyyeti li'l-Kitab, 2. Basım, 1442/1993.

Hillî, Cemâleddîn Ebû Mansur Hasan b. Yusuf el-Mutahhar Allâme. Menâhicu'l-yakîn fî usûli'd-dîn. thk. Muhammed Riza el-Ensârî el-Kummî. Kum: Yârân, 1416/1995.

Holoğlu, Yasemin. Câhız'da Tabiat Felsefesi. İstanbul: Marmara Üniversitesi, Sosyal Bilimler Enstitüsü, Yüksek Lisans Tezi, 2014.

İbn Hazm, Ebû Muhammed b. Alî b. Saîd ez-Zâhirî el-Endelûsî. el-Fasl: Dinler ve Mezhepler Tarihi. çev. Halil İbrahim Bulut. 3 Cilt. İstanbul: Türkiye Yazma Eserler Kurumu Başkanlığı, 2017.

Kādî Abdülcebbar, Ebü'l-Hasen Ahmed el-Hemedânî. el-Muhît bi't-teklif li'l-Kādî Abdilcebbâr cemea elHasan b. Ahmed b. Metteveyh. thk. Ömer Seyyid Azmî. Kāhire: ed-Dârü'l-Mısriyye li't-Te'lîf ve'tTerceme, t.y.

Kādî Abdülcebbar, Ebü'l-Hasen Ahmed el-Hemedânî. el-Muğnî fî ebvâbi't-tevhîd ve'l-adl XV (enNubuvvât ve'l-mu'cizât). thk. Mahmud Muhammed Kāsım, ed. İbrahim Mezkûr-Tâhâ Hüseyin. Kāhire: ed-Dârü'l-Misriyye, t.y.

Kādî Abdülcebbar, Ebü'l-Hasen Ahmed el-Hemedânî. el-Muğnîfî ebvâbi't-tevhîd ve'l-adl XVI (İcâzü'lKur'an). thk. Mahmud Muhammed Kāsım, ed. İbrahim Mezkûr-Tâhâ Hüseyin. Kāhire: ed-Dârü'lMisriyye, t.y.

Kādî Abdülcebbâr, Ebü'l-Hasen Ahmed el-Hemedânî. Şerhu'l-usûli'l-hamse. thk. Abdülkerim Osman. Kâhire: Mektebetü Vehbe, 1408/1988.

Kādî Abdülcebbâr, Ebü'l-Hasen Ahmed el-Hemedânî. Nedensellik Kitabı Kitâbü't-Tevlìd min kitâbi'lmuğnî. trc. Osman Demir. İstanbul: Klasik Yayınları, 2015.

Kandemir, Ahmet Mekin. Mu'tezilî Düşüncede Tabiat ve Nedensellik. İstanbul: Endülüs Yayınları, 2019. Kur'an-Kerim Meâli. çev. Halil Altuntaş - Muzaffer Şahin. Ankara: Diyanet İşleri Başkanlığı Yayınları, 12. Basım, 2011.

Kutluer, İlhan. "Gâiyyet”. Türkiye Diyanet Vakfı İslâm Ansiklopedisi. 13/292-295. İstanbul: Türkiye Diyanet Vakfı Yayınları, 1996. 
Martin, Richard Carleton. A Mu'tazilite Treatise on Prophethod and Miracle: Being Probably the bâb alâ l-Nubuvvah from the Ziyâdat al-sharh by Ebû Rashid al-Nîsâbûrî (Died First Half of the Fifty Century A. H.). Michigan: New York University. Doktora Tezi/Ph. D. Dissertation, 1975.

Mâverdî, Ebü'l-Hasan Alî b. Muhammed b. Habib. en-Nüket ve'l-uyûn tefsîru'l-Maverdî. thk. es-Seyyid b. Abdülmaksud b. Abdürrahim. 4 Cilt. Beyrut: Dârü'l-Kütübi'l-İlmiyye, 1412/1992.

Mülhim, Ebû Ali. el-Münâhi'l-felsefî inde'l-Câhız. Beyrut: Dâru't-Tali'a li’t-Tıba've'n-Neşr, 1998.

Nesefî, Ebü'l-Muîn Meymûn b. Muhammed. Tebstratü'l-edille fî usûli'd-dîn. thk. Hüseyin Atay-Şaban Ali Düzgün. 2 cilt. Ankara: Diyanet İşleri Başkanlı̆̆ı Yayınları, 2. Basım, 2003.

Şehristânî, Ebü'l-Feth Muhammed b. Abdülkerim. Kitâbü'l-Milel ve'n-nihal. thk. Muhammed b. Fethullah Bedrân. 2 cilt. Kāhire: Mektebetü'l-Enclo'l-Mısriyye, 2. Basım, 1328/1910.

Şerîf el-Murtazâ, Alî b. Hüseyin. ez-Zahîre fî ilmi'l-kelâm. nşr. Ahmed el-Hüseynî. Kum: Müessesetü’n-Neşri'l-İslâmî, 1411/1990.

Tâî Muhammed Bâsil-Milkâvî, Âmâl-Sabbârînî, Muhammed Saîd. "Çağdaş Fizik ve Müslüman Kelâmcılar Açısından Sebeplilik Kavramı”. trc. Kübra Şenel. Kutadgubilig Felsefe ve Bilim Araştırmaları Dergisi 23 (Mart 2013), 207-253.

Wolfson, H. Austryn. Kelâm Felsefeleri Müslüman-Hıristiyan-Yahûdî Kelamı. çev. Kasım Turhan. İstanbul: Kitabevi Yayınları, 2001. 